\title{
Global-scale evaluation of 22 precipitation datasets using gauge observations and hydrological modeling
}

\author{
Hylke E. Beck ${ }^{1}$, Noemi Vergopolan ${ }^{1}$, Ming Pan ${ }^{1}$, Vincenzo Levizzani ${ }^{2}$, Albert I. J. M. van Dijk ${ }^{3}$, Graham P. Weedon ${ }^{4}$, \\ Luca Brocca $^{5}$, Florian Pappenberger ${ }^{6}$, George J. Huffman ${ }^{7}$, and Eric F. Wood ${ }^{1}$ \\ ${ }^{1}$ Department of Civil and Environmental Engineering, Princeton University, Princeton, New Jersey, USA \\ ${ }^{2}$ National Research Council of Italy, Institute of Atmospheric Sciences and Climate (CNR-ISAC), Bologna, Italy \\ ${ }^{3}$ Fenner School of Environment \& Society, The Australian National University, Canberra, Australia \\ ${ }^{4}$ Met Office, Joint Centre for Hydro-Meteorological Research, Wallingford, UK \\ ${ }^{5}$ Research Institute for Geo-Hydrological Protection, National Research Council, Perugia, Italy \\ ${ }^{6}$ European Centre for Medium-Range Weather Forecasts, Shinfield Park, Reading, UK \\ ${ }^{7}$ Mesoscale Atmospheric Processes Laboratory, NASA Goddard Space Flight Center, Greenbelt, Maryland, USA
}

Correspondence to: Hylke E. Beck (hylkeb@ princeton.edu)

Received: 11 August 2017 - Discussion started: 14 August 2017

Revised: 23 October 2017 - Accepted: 26 October 2017 - Published: 8 December 2017

\begin{abstract}
We undertook a comprehensive evaluation of 22 gridded (quasi-)global (sub-)daily precipitation $(P)$ datasets for the period 2000-2016. Thirteen non-gauge-corrected $P$ datasets were evaluated using daily $P$ gauge observations from 76086 gauges worldwide. Another nine gaugecorrected datasets were evaluated using hydrological modeling, by calibrating the HBV conceptual model against streamflow records for each of 9053 small to mediumsized $\left(<50000 \mathrm{~km}^{2}\right)$ catchments worldwide, and comparing the resulting performance. Marked differences in spatiotemporal patterns and accuracy were found among the datasets. Among the uncorrected $P$ datasets, the satellite- and reanalysis-based MSWEP-ng V1.2 and V2.0 datasets generally showed the best temporal correlations with the gauge observations, followed by the reanalyses (ERA-Interim, JRA55, and NCEP-CFSR) and the satellite- and reanalysis-based CHIRP V2.0 dataset, the estimates based primarily on passive microwave remote sensing of rainfall (CMORPH V1.0, GSMaP V5/6, and TMPA 3B42RT V7) or near-surface soil moisture (SM2RAIN-ASCAT), and finally, estimates based primarily on thermal infrared imagery (GridSat V1.0, PERSIANN, and PERSIANN-CCS). Two of the three reanalyses (ERA-Interim and JRA-55) unexpectedly obtained lower trend errors than the satellite datasets. Among the corrected $P$ datasets, the ones directly incorporating daily gauge data (CPC Unified, and MSWEP V1.2 and V2.0) generally pro-
\end{abstract}

vided the best calibration scores, although the good performance of the fully gauge-based CPC Unified is unlikely to translate to sparsely or ungauged regions. Next best results were obtained with $P$ estimates directly incorporating temporally coarser gauge data (CHIRPS V2.0, GPCP-1DD V1.2, TMPA 3B42 V7, and WFDEI-CRU), which in turn outperformed the one indirectly incorporating gauge data through another multi-source dataset (PERSIANN-CDR V1R1). Our results highlight large differences in estimation accuracy, and hence the importance of $P$ dataset selection in both research and operational applications. The good performance of MSWEP emphasizes that careful data merging can exploit the complementary strengths of gauge-, satellite-, and reanalysis-based $P$ estimates.

\section{Introduction}

Precipitation $(P)$ is arguably the most important driver of the hydrological cycle, but also one of the most challenging to estimate (Daly et al., 2008; Michaelides et al., 2009; Kidd and Levizzani, 2011; Tapiador et al., 2012). Over recent decades, several gridded $P$ datasets have been developed that are suitable for large-scale hydrological applications (for overviews, see Table 1, Beck et al., 2017b, http://ipwg.isac. cnr.it, and http://reanalyses.org). The datasets differ in terms 
of design objective (temporal homogeneity, instantaneous accuracy, or both), data sources (radar, gauge, satellite, analysis, or reanalysis, or combinations thereof), spatial resolution (from 0.05 to $2.5^{\circ}$ ), spatial coverage (from continental to fully global), published temporal resolution (from $30 \mathrm{~min}$ to monthly), temporal span (from $\sim 1$ to 115 years), and latency (from $\sim 3 \mathrm{~h}$ to several years).

A plethora of studies addressed the important task of evaluating these $P$ datasets to understand their respective advantages and limitations (see reviews by Gebremichael, 2010; Maggioni et al., 2016). Most studies assessed accuracy using independent gauge observations (e.g., Hirpa et al., 2010; Buarque et al., 2011; Bumke et al., 2016; Alijanian et al., 2017) or gauge-adjusted radar fields (e.g., AghaKouchak et al., 2011; Islam et al., 2012), while others merely compared their spatio-temporal patterns (e.g., Kidd et al., 2013). Still others quantified the performance of different $P$ datasets using hydrological modeling, by comparing simulated and observed values of river discharge $(Q$; e.g., Collischonn et al., 2008; Behrangi et al., 2011; Bitew et al., 2012; Falck et al., 2015) or soil moisture (e.g., Pan et al., 2010; Albergel et al., 2013; Martens et al., 2017). More recently, Massari et al. (2017) assessed the performance of different $P$ datasets using triple collocation. Marked differences in spatio-temporal $P$ patterns and accuracy have been found among the datasets, even among those employing the same data sources. This highlights the critical importance of dataset choice for research and operational applications alike.

Previous evaluation studies used a wide variety of evaluation approaches and performance metrics (Ebert, 2007; Gebremichael, 2010; Loew et al., 2017). However, many studies considered only a single $P$ dataset (e.g., Scheel et al., 2011; Nair and Indu, 2017) or disregarded (re)analysis-based $P$ datasets (e.g., Moazami et al., 2013; Mei et al., 2014; Zambrano-Bigiarini et al., 2017), despite their demonstrated superior performance in cold climates (Ebert et al., 2007; Beck et al., 2017b; Massari et al., 2017). In addition, some studies re-used gauge observations already incorporated in some of the $P$ datasets to determine their accuracy (e.g., Chen et al., 2013; Ashouri et al., 2016; Zambrano-Bigiarini et al., 2017), precluding independent validation. Furthermore, to our knowledge, so far no study has accounted for differences in the exact UTC boundary of the $24 \mathrm{~h}$ accumulation period of daily gauge reports when evaluating $P$ datasets, potentially confounding the results. Moreover, studies employing hydrological modeling generally used $Q$ observations from a small number of catchments (e.g., Bitew et al., 2012, and Tang et al., 2016; both used only one) and did not attempt to recalibrate the hydrological model for each $P$ dataset individually (e.g., Su et al., 2008; Li et al., 2013), leading to combined rainfall and model uncertainty that is not easily interpreted. Finally, many have a regional (subcontinental) focus (Maggioni et al., 2016), and therefore it is not clear to what extent the results can be generalized.
Nevertheless, there have also been several (quasi-)global $P$ dataset evaluation studies that produced general insights (e.g., Adler et al., 2001; Fekete et al., 2004; Voisin et al., 2008; Bosilovich et al., 2008; Tian and Peters-Lidard, 2010; Lorenz and Kunstmann, 2012; Yong et al., 2015; Herold et al., 2015; Gehne et al., 2016; Massari et al., 2017). These studies revealed that satellites (reanalyses) exhibit superior performance at low (high) latitudes dominated by intense, localized convective (persistent, large-scale stratiform) $P$ systems. However, none of these studies took advantage of the vast number of $P$ gauge observations contained in the freely available GHCN-D (Menne et al., 2012) and GSOD (https://data.noaa.gov) databases. Among the only two studies employing hydrological modeling, Fekete et al. (2004) performed monthly simulations and did not compare the results against observed $Q$, while Voisin et al. (2008) used monthly observed $Q$ data from only nine very large catchments $\left(>290000 \mathrm{~km}^{2}\right)$. Moreover, several promising recently released or revised $P$ datasets, such as CHIRPS V2.0, MSWEP V2.0, and PERSIANN-CDR V1R1 (see Table 1), have not been thoroughly evaluated yet at a (quasi-)global scale.

Our objective was to undertake the most comprehensive global-scale $P$ dataset evaluation to date. We evaluated 13 non-gauge-corrected $P$ datasets using daily $P$ gauge observations from 76086 gauges worldwide. Another nine gaugecorrected $P$ datasets were evaluated using hydrological modeling for 9053 catchments $\left(<50000 \mathrm{~km}^{2}\right)$ worldwide, by calibrating a hydrological model. The expectation is that such a large number of $P$ datasets and large number of observations should lead to more generally valid conclusions and allow us to explicitly compare the performance among climate types and regions (Andréassian et al., 2007; Gupta et al., 2014).

\section{Data and methods}

\subsection{P datasets}

Table 1 presents the 22 gridded $P$ datasets included in the evaluation. The datasets were classified as either uncorrected, meaning that their temporal dynamics depend entirely on satellite and/or reanalysis data, or gauge-corrected, meaning that their temporal dynamics depend at least partly on gauge data (hence precluding an independent evaluation using $P$ gauge observations). We included seven datasets based exclusively on satellite data (CMORPH V1.0, GSMaP, GridSat V1.0, PERSIANN, PERSIANN-CCS, SM2RAINASCAT, and TMPA 3B42RT V7), three based exclusively on reanalysis data (ERA-Interim, JRA-55, and NCEP-CFSR), and three incorporating both satellite and reanalysis data (CHIRP V2.0, and MSWEP-ng V1.2 and V2.0). Among the gauge-corrected datasets, four combined gauge and satellite data (CMORPH-CRT, GPCP-1DD V1.2, PERSIANNCDR V1R1, and TMPA 3B42 V7), one combined gauge 


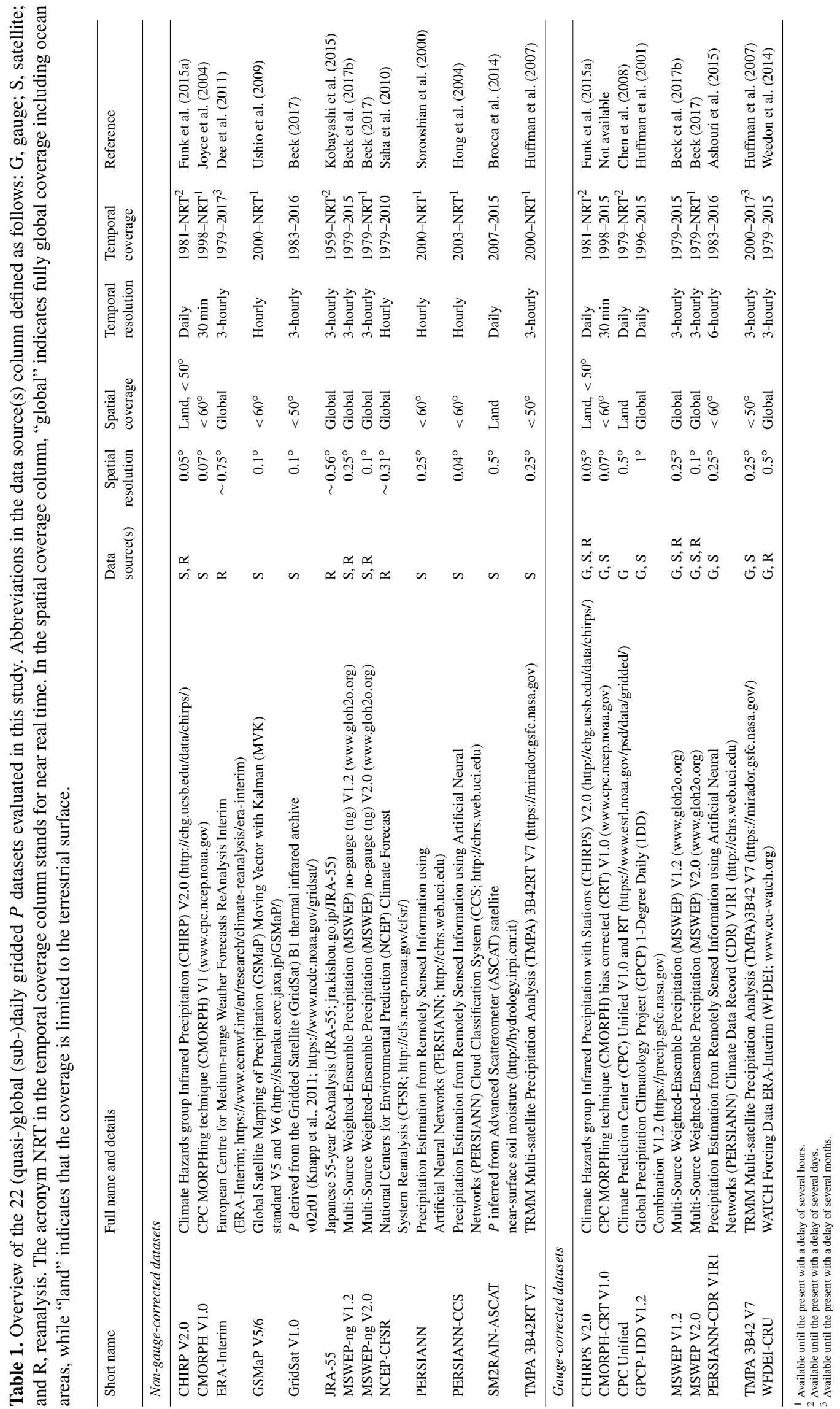


and reanalysis data (WFDEI-CRU), while three combined gauge, satellite, and reanalysis data (CHIRPS V2.0, and MSWEP V1.2 and V2.0). We also included a fully gaugebased dataset (CPC Unified). For clarity and reproducibility, we report dataset version numbers throughout the study for the datasets for which this information was available. We only included datasets with a temporal span of $>8$ years.

\subsection{Performance evaluation using gauge observations}

The performance of the 13 uncorrected $P$ datasets (see Table 1) was evaluated using daily gauge observations from across the globe. Our collection of gauge observations was compiled from the Global Historical Climatology NetworkDaily (GHCN-D) database (Menne et al., 2012), the Global Summary of the Day (GSOD) database (https://data.noaa. gov), the Latin American Climate Assessment \& Dataset (LACA\&D) database (http://lacad.ciifen-int.org), the Chile Climate Data Library (http://www.climatedatalibrary.cl), and national databases for Mexico, Brazil, Peru, and Iran. To discard erroneous observations, each gauge record was subjected to several quality checks as described in Beck (2017). Only gauges with $>365$ days of valid data (not necessarily consecutive) during 2000-2016 were retained. To minimize temporal mismatches in gauge and gridded $P$ time series, we used the gauge reporting times from Beck (2017) to shift the records of gauges with reporting times $>+12 \mathrm{~h}$ UTC backward by 1 day, and the records of gauges with reporting times $<-12 \mathrm{~h}$ UTC forward by 1 day. In total 76086 gauges had sufficient quality-controlled data for the evaluation.

We considered the following five performance metrics to evaluate the $P$ datasets in terms of temporal dynamics: (i) Pearson linear correlation coefficient $(R)$ calculated for 3-day means ( $R_{3 \text { day }}$ ); (ii) $R$ calculated for monthly means $\left(R_{\text {monthly }}\right)$; (iii) $R$ calculated for 6-month Standardized Precipitation Index values $\left(R_{\text {SPI-6 }}\right.$; Hayes et al., 1999$)$; (iv) mean absolute error (MAE; mm month ${ }^{-1}$ ) for monthly means; and (v) the trend error (the difference between gaugeand dataset-based linear regression slopes calculated from annual anomalies; $\left.\% \mathrm{yr}^{-1}\right)$. We opted for MAE instead of the more widely used root mean square error (RMSE) because the errors are unlikely to follow a normal distribution (Chai and Draxler, 2014; Willmott et al., 2017). We used 3day rather than daily means for $R_{3}$ day to minimize the impact of any residual mismatches in the UTC boundary of the $24 \mathrm{~h}$ accumulation period between the gauges and datasets. The $R_{3}$ day metric was only calculated if $\geq 603$-day contemporaneous gauge and dataset values were available, while the $R_{\text {monthly }}, R_{\mathrm{SPI}-6}$, and MAE metrics were only calculated if $\geq 12$ monthly contemporaneous gauge and dataset values were available.

To evaluate the $P$ datasets in terms of long-term mean climate indices, we considered the following four metrics: (i) long-term relative bias, defined as $[\bar{s}-\bar{o}] /[\bar{s}+\bar{o}]$, where $\bar{s}$ and $\bar{o}$ represent the dataset- and gauge-based long-term means, respectively; (ii) annual number of dry days error (using a $0.5 \mathrm{~mm} \mathrm{~d}^{-1}$ threshold to identify dry days, similar to Akinremi et al., 1999, Haylock et al., 2008, and Driouech et al., 2009); and (iii) 99th and 99.9th percentile daily $P$ error $\left(\mathrm{mm} \mathrm{d}^{-1}\right)$. The bias and trend error metrics were only calculated if $>5$ years of daily contemporaneous gauge and dataset values were available.

\subsection{Performance evaluation using hydrological modeling}

The performance of the nine gauge-corrected $P$ datasets (see Table 1) was evaluated using hydrological modeling for 9053 catchments. Our collection of $Q$ observations was compiled from the same three sources as Beck et al. (2015), viz. (i) the US Geological Survey (USGS) Geospatial Attributes of Gages for Evaluating Streamflow (GAGES)-II database (Falcone et al., 2010); (ii) the Global Runoff Data Centre (GRDC; http://www.bafg.de/GRDC/); and (iii) the Australian Peel et al. (2000) database. We only used catchments $<50000 \mathrm{~km}^{2}$ because applying a daily lumped hydrological model in very large catchments would result in spatial averaging of the forcings over very large areas, confounding the daily runoff generation and water balance calculations. In addition, catchments were required to have a $Q$ record length $>365$ days (not necessarily consecutive) during 2000-2012 (the common temporal coverage of the $P$ datasets), resulting in 9053 catchments that were suitable for the evaluation (5th, 50th, and 95th catchment-size percentiles equal to 9, 633 , and $18468 \mathrm{~km}^{2}$, respectively).

For each catchment, the HBV conceptual hydrological model (Bergström, 1992; Seibert and Vis, 2012) was calibrated in a lumped fashion against $Q$ observations using daily $P$ time series from each of the datasets to force the model. The model was selected because of its agility, computational efficiency, and widespread successful application (e.g., Te Linde et al., 2008; Deelstra et al., 2010; Plesca et al., 2012; Beck et al., 2013; Valéry et al., 2014; Vetter et al., 2015; Beck et al., 2017a). For the calibration, we employed the $(\mu+\lambda)$ evolutionary algorithm (Ashlock, 2010; Fortin et al., 2012) with the population size $(\mu)$ set to 20 , the recombination pool size $(\lambda)$ set to 40 , and the number of generations set to 12 (amounting to 480 model runs per catchment per $P$ dataset and approximately 40 million model runs in total). See Beck et al. (2016) and (2017b) for more details on the hydrological model, calibration algorithm, model parameter ranges, $Q$ observations, $E_{\mathrm{p}}$ forcing, and $T_{\mathrm{a}}$ forcing. We recognize that using data from different sources may bias results as the water balances are unlikely to be closed.

As an objective function we used the Nash and Sutcliffe (1970) efficiency (NSE) computed between 3-day mean simulated and observed $Q$ time series. We used the NSE, despite the criticism it has received (e.g., Schaefli and Gupta, 2007; Jain and Sudheer, 2008; Criss and Winston, 2008; Gupta et al., 2009), because (i) it is highly sensitive to peak flows 
(Krause et al., 2005), which is desirable for this study given that peak flows are primarily driven by the precipitation forcing, whereas low flows are primarily driven by the hydrological model structure and parameters; (ii) besides peak flows, NSE is also sensitive to the long-term bias (Gupta et al., 2009), another important feature of the hydrograph primarily influenced by the precipitation forcing; and (iii) most hydrologists and meteorologists are familiar with the NSE (Moriasi et al., 2007), facilitating the interpretation of the obtained values. We used 3-day rather than daily mean $Q$ time series for the NSE calculation to reduce the impact of temporal mismatches in simulated and observed $Q$ peaks. A higher calibration NSE generally implies that the $P$ dataset in question is more consistent with the $Q$ observations and potential evaporation $\left(E_{\mathrm{p}}\right)$ estimates and thus that the $P$ dataset is more accurate.

\section{Results and discussion}

\subsection{Performance for temporal dynamics}

The temporal dynamics of the 13 uncorrected $P$ datasets were evaluated using daily $P$ observations from 76086 gauges around the globe. Table 2 presents summary statistics separately for the gauges located at latitudes $<40^{\circ}$ for all datasets, and for the gauges located at latitudes $\geq 40^{\circ}$ only for the datasets covering the entire terrestrial surface (i.e., MSWEP-ng V1.2 and V2.0, and the reanalyses). In terms of temporal correlations ( $R_{3}$ day,$R_{\text {monthly }}$, and $R_{\mathrm{SPI}-6}$ ), the satellite- and reanalysis-based MSWEP-ng datasets performed overall slightly better than the reanalyses (ERAInterim, JRA-55, and NCEP-CFSR) and the satellite- and reanalysis-based CHIRP V2.0 dataset, which in turn performed slightly better than the satellite datasets based primarily on passive microwave retrievals (CMORPH V1.0, GSMaP V5/6, and TMPA 3B42RT V7) and near-surface soil moisture (SM2RAIN-ASCAT), which in turn performed slightly better than the satellite datasets based primarily on thermal infrared imagery (GridSat V1.0, PERSIANN, and PERSIANN-CCS). The high correlations obtained using both versions of MSWEP-ng underscore the effectiveness of merging multiple satellite and reanalysis datasets (Beck et al., 2017b). Indeed, Ciabatta et al. (2017) found the soil moisture-based rainfall dataset SM2RAIN-CCI to exhibit considerably better 5-day correlations with MSWEP V1.2 than with the comprehensive gauge-based GPCC dataset (Schneider et al., 2014), even though the latter was used to train the SM2RAIN algorithm. In agreement with our results, Stillman et al. (2016) found reanalyses to outperform infrared- and passive microwave-based satellite datasets in Arizona. SM2RAIN-ASCAT was found to perform similarly to TMPA 3B42RT V7, in agreement with Brocca et al. (2014), suggesting that soil moisture-based approaches provide a promising additional source of rainfall estimates.
The better performance of the microwave-based datasets compared to infrared-based ones is in line with previous evaluations (e.g., Hirpa et al., 2010; Peña Arancibia et al., 2013; Cattani et al., 2016) and attributed to the indirect relationship between cloud-top infrared brightness temperatures and surface rainfall (Stephens and Kummerow, 2007). Contrary to expectation, PERSIANN-CCS attained lower median correlations than both GridSat V1.0 and PERSIANN, despite using a more sophisticated algorithm and higher spatial resolution (Hong et al., 2004). This indicates that a higher spatial resolution does not necessarily lead to more skillful estimates, and that there may be limited additional value to be gained from extracting cloud-patch characteristics. GridSat V1.0 $P$ estimates have been derived by a cumulative distribution function (CDF) matching the entire period of infrared data to a reference $P$ distribution. Better results might be obtained by CDF matching on a monthly or seasonal climatological basis, to account for intra-annual variability in the infrared $-P$ relationship.

Figure 1 presents global $R_{3 \text { day }}$ maps for a selection of eight $P$ datasets, permitting a geographical interpretation of the results (see the Supplement for global maps of the other performance metrics). All datasets performed relatively poorly $\left(R_{3 \text { day }}<0.5\right)$ in arid and tropical regions, due to the often highly localized and shortlived nature of the convective rainfall that dominates (Cecil et al., 2014). Sub-cloud evaporation of falling rain potentially constitutes an additional confounding factor in arid regions (Dinku et al., 2016). Africa showed the lowest $R_{3}$ day values overall, probably due to the high prevalence of convective rain events over most of the continent (Cecil et al., 2014). Conversely, all datasets performed relatively well $\left(R_{3}\right.$ day $\left.\geq 0.5\right)$ in moist mid-latitude regions with mild winters (e.g., the southeastern US, eastern South America, and eastern China). In accordance with several previous global evaluations (e.g., Barrett et al., 1994; Xie and Arkin, 1997; Adler et al., 2001; Ebert et al., 2007; Massari et al., 2017), the reanalyses exhibited lower skill levels than the microwave- and infraredbased satellite datasets in the tropics, whereas the opposite is true for colder regions (latitudes $>40^{\circ}$ ). The comparatively high skill of the reanalyses in colder regions reflects the ability of atmospheric models to simulate synoptic-scale weather systems (Haiden et al., 2012; Zhu et al., 2014). The comparatively low skill of the reanalyses in the tropics is attributable to deficiencies in the sub-grid convection parameterization schemes (Arakawa, 2004), as well as issues in the land surface parameterization and unrealistic strengthening and northward displacement of the monsoon cycle ( $\mathrm{Di}$ Giuseppe et al., 2013). Multi-scale modeling frameworks incorporating high-resolution $(<4 \mathrm{~km})$, convection-permitting models, which negate the need for sub-grid convection parameterization schemes, provide a promising way forward in this regard (Prein et al., 2015; Clark et al., 2016).

MSWEP V2.0 obtained lower mean annual $P$ trend errors than the other $P$ datasets (Table 2 and Fig. S5 in the Supple- 


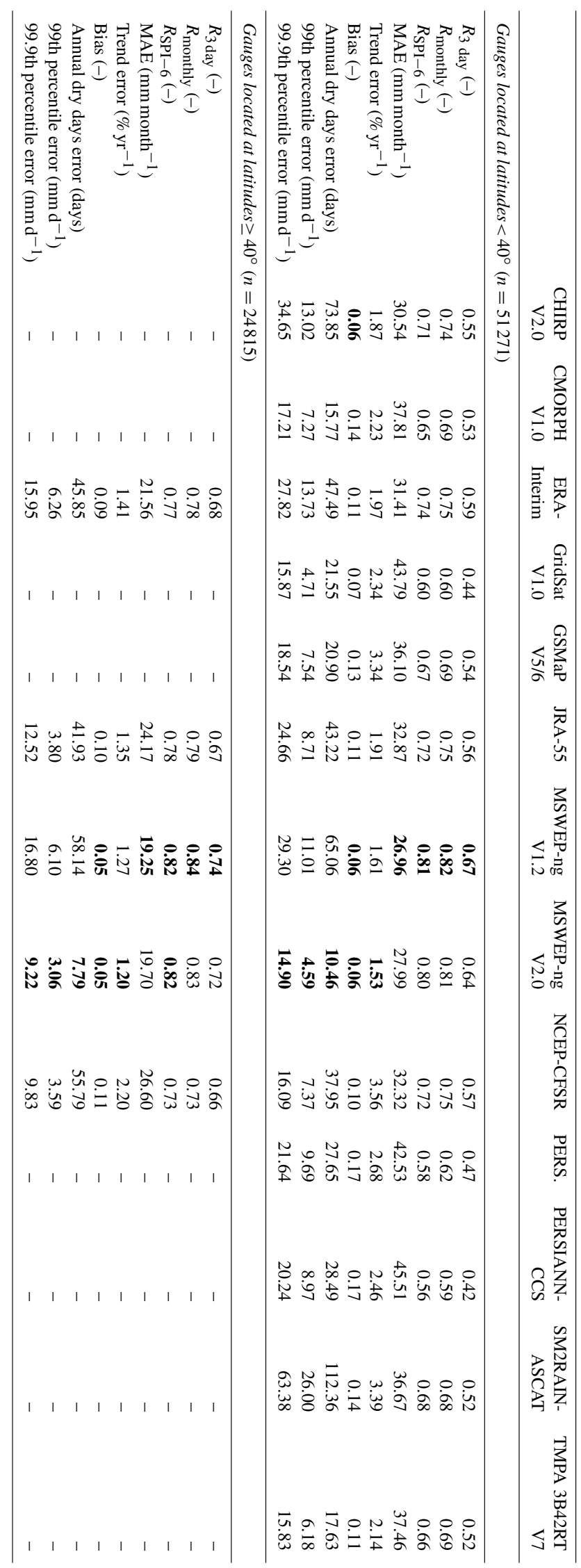

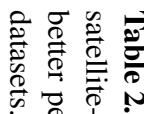

궁

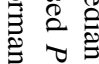

त.

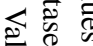

蒠

․ㅇํㄹ

它完

웅

$\overrightarrow{8} \cong$

8 .

$\stackrel{0}{\circ}$

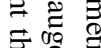

क

赵

揢官

$\stackrel{2}{2}$

용.

है हे

IV IV

ㄹ..$\circ$

용 प्र

居导

里象

응

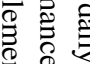

$\Xi \underset{8}{\Xi}$

용요

a․

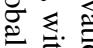

F

莺 후의

छ.

용.

๙ิ

\&

$\overrightarrow{0} \circlearrowright$

훙

$\overrightarrow{0}_{0}$

क

贾

용.

官 䒕

요용

象劳

触 
(a) CHIRP V2.0

(b) CMORPH V1.0

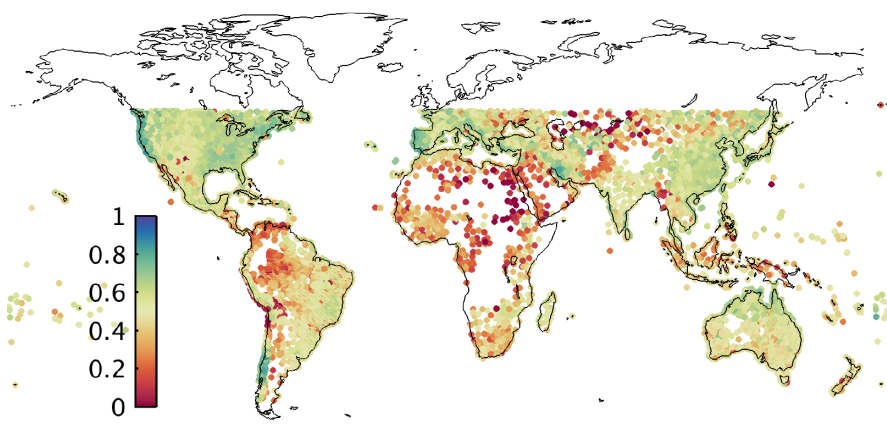

(c) ERA-Interim (b) CMORPH V1.0

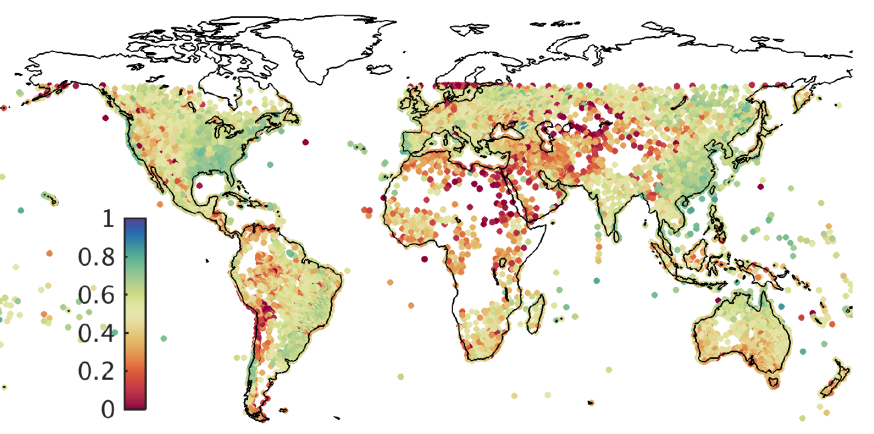

(d) MSWEP-ng V2

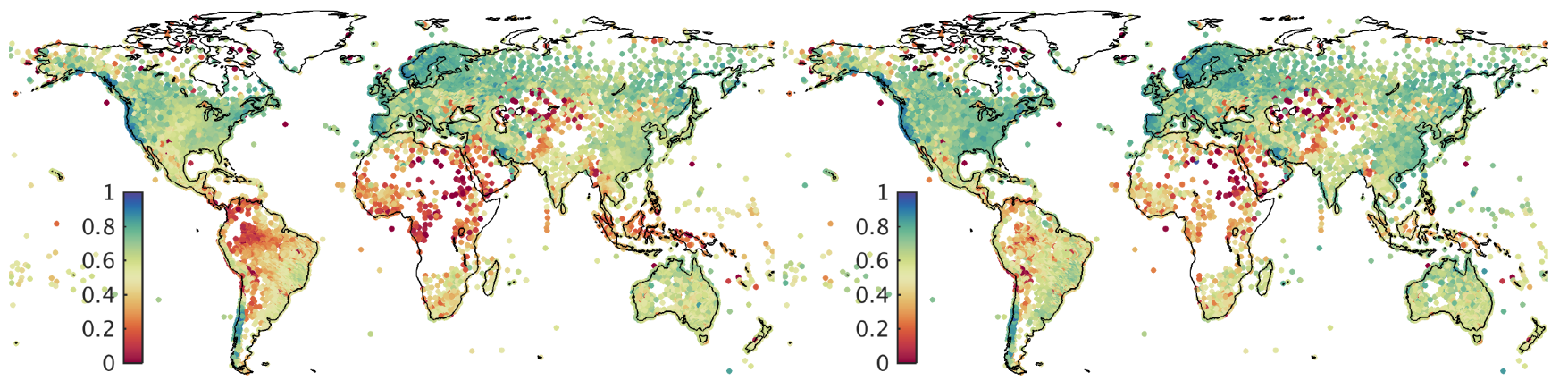

(e) NCEP-CFSR

(f) PERSIANN-CCS

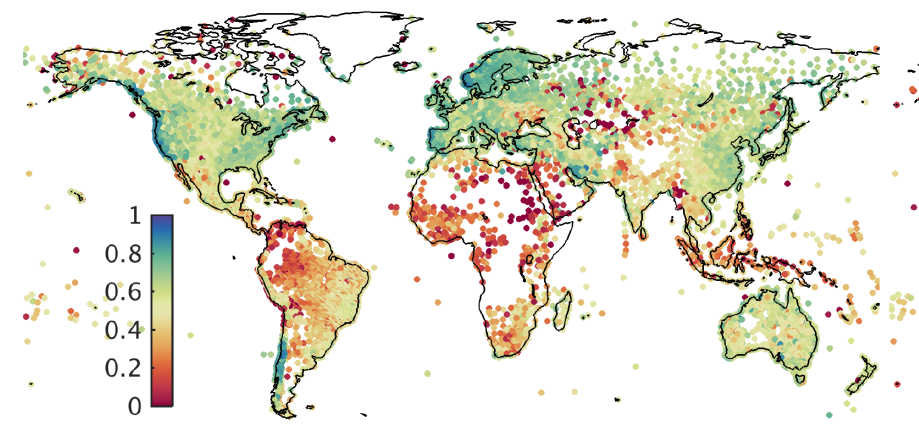

(g) SM2RAIN-ASCAT

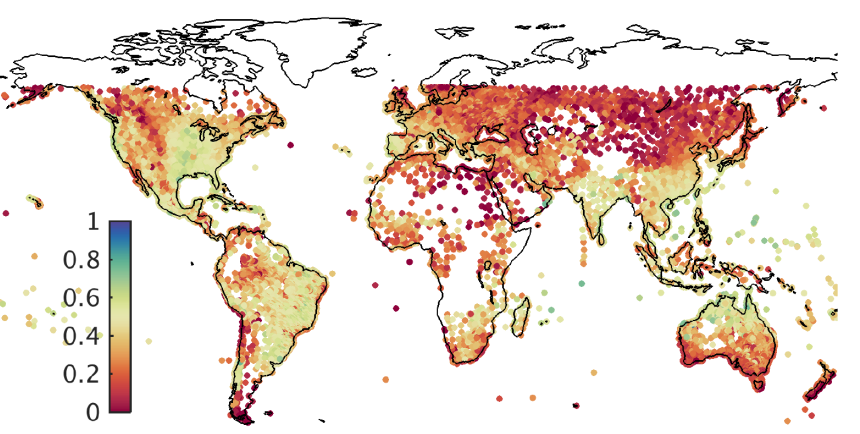

(h) TMPA 3B42RT V7

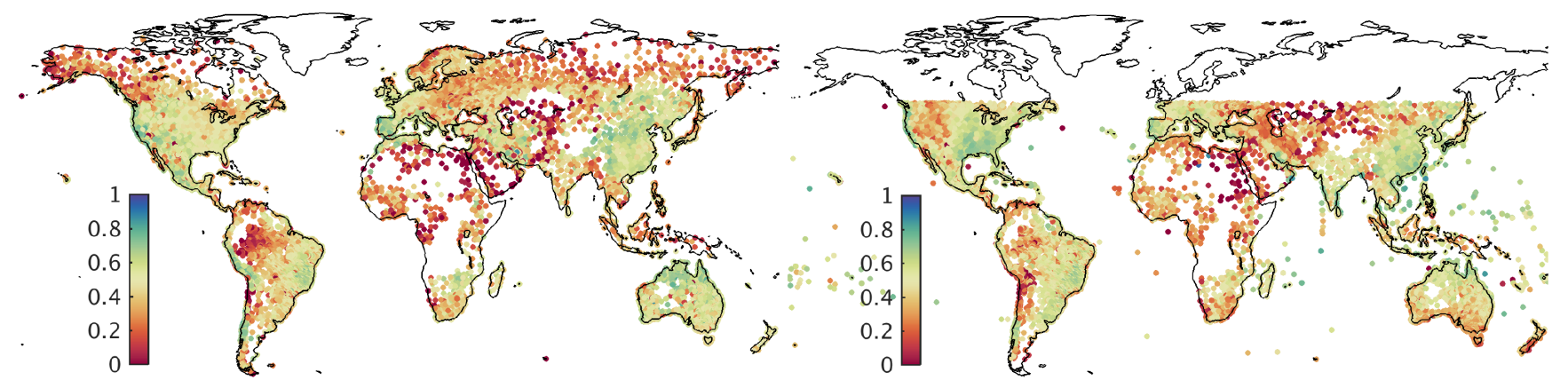

Figure 1. For a selection of the evaluated uncorrected $P$ datasets, temporal correlations between 3-day mean gauge- and dataset-based $P$ time series $\left(R_{3}\right.$ day $)$. Each data point represents a gauge. See the Supplement for global maps of the other performance metrics. 
ment). Two of the three reanalyses (ERA-Interim and JRA55) provided more reliable trends than the satellite datasets, contrary to the common assumption that reanalyses tend to contain temporal discontinuities due to changes in the assimilated observations (Bengtsson et al., 2004; Lorenz and Kunstmann, 2012; Kang and Ahn, 2015). However, our evaluation covers a relatively short period (2000-2016) during which the assimilated observations did not change considerably (Saha et al., 2010; Dee et al., 2011; Kobayashi et al., 2015). Among the satellite datasets, SM2RAIN-ASCAT provided the least accurate $P$ trends, probably due to the use of two ASCAT sensors after 2013 (on-board MetOp-A and MetOp-B) which artificially increased rainfall amounts obtained using SM2RAIN (separate calibrations for 2007-2012 and 2013-2015 are necessary but yet to be performed). Among the reanalyses, NCEP-CFSR performed worst. Following previous authors (Saha et al., 2010; Wang et al., 2013), we speculate that this may be attributable to the six parallel-run streams of analysis covering different periods, which have been combined to generate the final dataset. The relatively small mean annual $P$ trend errors obtained for the different datasets (ranging from 1.53 to $3.56 \% \mathrm{yr}^{-1}$ ) provide some confidence in the ability to infer significant trends from the various datasets. However, trends for variables measured over shorter temporal scales (e.g., annual maxima or percentiles) are likely to be subject to much greater uncertainty. We expect the dataset performance ranking to be similar for the period prior to the year 2000; however, additional studies are necessary to confirm this.

\subsection{Performance for climate indices}

The performance of the 13 uncorrected $P$ datasets in terms of several long-term climate indices is summarized in Table 2, listing summary statistics for $P$ gauges at latitudes $<40$ and $\geq 40^{\circ}$ (for the five datasets covering the entire terrestrial surface), respectively. In terms of bias, the reanalyses performed better overall than the satellite datasets (Table 2). Although CHIRP V2.0, GridSat V1.0, and MSWEP-ng V1.2 and V2.0 obtained the best bias scores, these datasets use the gaugebased CHPclim (Funk et al., 2015b) or WorldClim (Fick and Hijmans, 2017) datasets to determine their long-term mean. The spread in the range of bias scores among the datasets was generally greatest over topographically complex regions (notably the Rockies, Andes, and Hindu Kush), and in arid regions (notably the Sahara and the Arabian and Gobi deserts; Fig. S6), demonstrating the particular difficulty of estimating $P$ in these regions (Fekete et al., 2004; Hirpa et al., 2010; Xu et al., 2017; Kim et al., 2017). All fully global datasets exhibited positive biases at high northern latitudes, probably because the $P$ gauge data used for evaluation were not corrected for wind-induced under-catch (Groisman and Legates, 1994; Rasmussen et al., 2012; Kauffeldt et al., 2013).

In terms of the annual number of dry days, the datasets exhibited a particularly large spread in performance, with
MSWEP-ng V2.0 outperforming the other datasets by a substantial margin (Table 2 and Fig. S7). The dramatic improvement in MSWEP-ng V2.0 compared to V1.2 is mainly attributable to the CDF corrections introduced in V2, which eliminate the drizzle caused by averaging multiple data sources (Beck, 2017). The infrared- and microwave-based satellite datasets also performed reasonably well, although the $P$ frequency was generally overestimated at low and mid latitudes and underestimated at high latitudes, reflecting the difficulty of detecting $P$ signals at high latitudes (Ferraro et al., 1998; Ebert et al., 2007; Kidd and Levizzani, 2011; Kidd et al., 2012; Laviola et al., 2013). Conversely, the reanalyses consistently underestimated the number of dry days across the globe, due to the presence of spurious drizzle caused by deficiencies in the representation and/or parameterization of the physical processes governing $P$ generation (Zolina et al., 2004; Lopez, 2007; Sun et al., 2006; Skok et al., 2015). SM2RAIN-ASCAT also consistently underestimated the number of dry days due to the presence of spurious drizzle, in this case due to the relatively noisy soil moisture retrievals (Crow et al., 2011; Brocca et al., 2014) and the use of the already fairly wet ERA-Interim dataset for the algorithm calibration. CHIRP V2.0 also exhibited too few dry days, which is attributed to the use of linear regression equations to estimate 5-day mean $P$ from infrared-based cold-cloud duration values (Funk et al., 2015a). Forcing a hydrological model with $P$ data overestimating the frequency of low-intensity rainfall events is likely to result in overestimated evaporation and underestimated runoff, particularly in regions with high soil or canopy water storage capacities.

The 99th and 99.9th percentile daily $P$ errors measure the error in the magnitude of storms with return periods of 100 days and 2.7 years, respectively (Table 2 and Figs. S8 and S9, respectively). MSWEP-ng V2.0 performed best in this respect, whereas CHIRP V2.0, the reanalyses, MSWEPng V1.2, and particularly SM2RAIN-ASCAT consistently underestimated the 99th and 99.9th percentile storm magnitudes. However, some degree of underestimation would be expected, given the spatial-scale mismatch between gauge observations and grid-cell averages (see, e.g., Maraun, 2013), particularly for $P$ datasets with a coarse spatial resolution (see Table 1). Nevertheless, for the reanalyses the underestimation is probably primarily attributable to the aforementioned model uncertainties. For MSWEP-ng V1.2, it is due to the attenuating effect of merging multiple data sources (Beck et al., 2017b). For SM2RAIN-ASCAT, the strong underestimation of storm magnitudes may at least partly be due to signal loss induced by soil saturation (Brocca et al., 2014). Among the microwave- and infrared-based satellite datasets, PERSIANN-CCS showed the greatest spatial variability in storm magnitude bias. The generally strong differences in spatial performance patterns among datasets highlight the difficulty of generalizing the findings of regional (sub-continental) evaluation studies. 


\subsection{Performance evaluation using hydrological modeling}

The performance of the nine gauge-corrected $P$ datasets (see Table 1) was evaluated using hydrological modeling for 9053 catchments around the globe. Table 3 presents median calibration NSE scores obtained using the different $P$ datasets for different climate zones. The overall performance ranking of the datasets from best to worst (\% of catchments in which the dataset performed best between parentheses) is MSWEP V2.0 (45.5\%), MSWEP V1.2 $(21.5 \%)$, CPC Unified (15.9\%), WFDEI-CRU (5.0\%), TMPA 3B42 V7 (3.3\%), CMORPH-CRT V1.0 (2.6\%), CHIRPS V2.0 (2.5\%), PERSIANN-CDR V1R1 (2.1\%), and GPCP-1DD V1.2 (1.6\%). Thus, the datasets directly incorporating daily gauge data (CPC Unified, and MSWEP V1.2 and V2.0) overall outperformed the ones directly incorporating 5-day (CHIRPS V2.0) or monthly (GPCP-1DD V1.2, TMPA 3B42 V7, and WFDEI-CRU) gauge data, which in turn outperformed PERSIANN-CDR V1R1. Rather than using gauge observations directly for corrections, PERSIANNCDR V1R1 is adjusted to match the satellite- and gaugebased GPCP dataset (monthly temporal and $2.5^{\circ}$ spatial resolution). It is noted that some of the datasets, such as CHIRPS V2.0 and PERSIANN-CDR V1R1, have not been specifically designed to provide the best instantaneous accuracy, but rather to achieve the most temporally homogeneous record possible. Furthermore, the good performance of the exclusively gauge-based CPC Unified is unlikely to generalize to regions with sparse rain gauge networks.

Figure 2 presents global maps with calibration NSE values obtained for a selection of the best performing $P$ datasets, while Fig. 3 shows which of these $P$ datasets obtained the highest calibration NSE for each catchment. All $P$ datasets provided low calibration NSE scores $(<0.3)$ over the US Great Plains, consistent with several previous studies using different hydrological models and forcing datasets (e.g., Newman et al., 2015; Bock et al., 2016; Essou et al., 2016). It reflects the spatio-temporally highly intermittent rainfall regime combined with a strongly nonlinear rainfall-runoff response (Pilgrim et al., 1988). Low calibration scores were also found in northern Alaska, presumably due to $P$ underestimation (Kauffeldt et al., 2013); in Namibia and Zambia, probably partly due to the importance of convective rainfall and partly due to the $Q$ data quality (Li et al., 2013); and in Hawaii, which we suspect are due to flow overestimations caused by (i) erroneous rating curves, as visual inspection of the records revealed the presence of drift errors, and (ii) submarine groundwater discharge (Garrison et al., 2003), which is not explicitly accounted for by HBV. In North America, Europe, Japan, Australia, New Zealand, and southern and western Brazil, MSWEP V2.0 generally exhibited the best performance, whereas in Central America, and in central and eastern Brazil, CHIRPS V2.0 tended to perform best. No obviously best estimate could be identified for Africa, em- phasizing the challenge of hydrological modeling in Africa (Sylla et al., 2013; Beck et al., 2017a). In summary, there are some $P$ datasets that consistently outperform others regionally, but there is not one that performs best everywhere (Barrett et al., 1994).

The good performance obtained for CPC Unified, CHIRPS V2.0, and MSWEP V1.2 and V2.0 underscores the importance of using sub-monthly gauge observations to improve $Q$ simulations. Few $P$ datasets currently incorporate sub-monthly gauge data, possibly because of the better global-scale availability of monthly gauge data, the lack of reliable information on the $24 \mathrm{~h}$ accumulation time for the large majority of gauges across the globe, and the difficulty of applying daily rather than monthly gauge corrections (Vila et al., 2009). However, a wealth of daily gauge data is currently freely available (Menne et al., 2012; Funk et al., 2015a), and sub-daily satellite and reanalysis $P$ estimates provide an efficient and consistent means to infer the most probable UTC boundary of the $24 \mathrm{~h}$ accumulation period for any gauge with observations during the satellite era (1979-present; Beck, 2017).

Most previous studies using hydrological modeling to evaluate the accuracy of $P$ datasets had a regional or subcontinental focus, used $Q$ observations from a relatively small number of catchments, considered only a few $P$ datasets, did not consider reanalysis-based $P$ datasets, or did not re-calibrate the hydrological model for each $P$ dataset (e.g., Voisin et al., 2008; Su et al., 2008; Bitew et al., 2012; Tang et al., 2016). Here, we used 9053 catchments covering all climate zones and latitudes, considered a diverse range of $P$ datasets, and re-calibrated the model for each $P$ dataset, to maximize the generalizability of our findings. Nevertheless, our catchments are predominantly located in regions with dense $P$ gauge networks (i.e., the conterminous US, Europe, and parts of Australia). Therefore, our results may not unequivocally generalize to regions with sparse $P$ gauge networks. Use of another calibration objective function, hydrological model, or $T_{\mathrm{a}}$ or $E_{\mathrm{p}}$ forcing may lead to slightly different results, although we consider it unlikely to change the overall performance ranking of the $P$ datasets. Finally, a poor score for a particular $P$ dataset may also simply reflect a systematic bias that could be easily corrected.

\section{Conclusions}

This study may represent the most comprehensive globalscale $P$ dataset evaluation to date. We evaluated 13 uncorrected $P$ datasets using $P$ observations from 76086 gauges, and 9 gauge-corrected ones using hydrological modeling for 9053 catchments $\left(<50000 \mathrm{~km}^{2}\right)$. Our results can be summarized as follows.

1. Among the non-gauge-corrected $P$ datasets, MSWEPng V1.2 and V2.0, based on optimal merging of multiple satellite and reanalysis $P$ datasets, provided the 
(a) CHIRPS V2.0

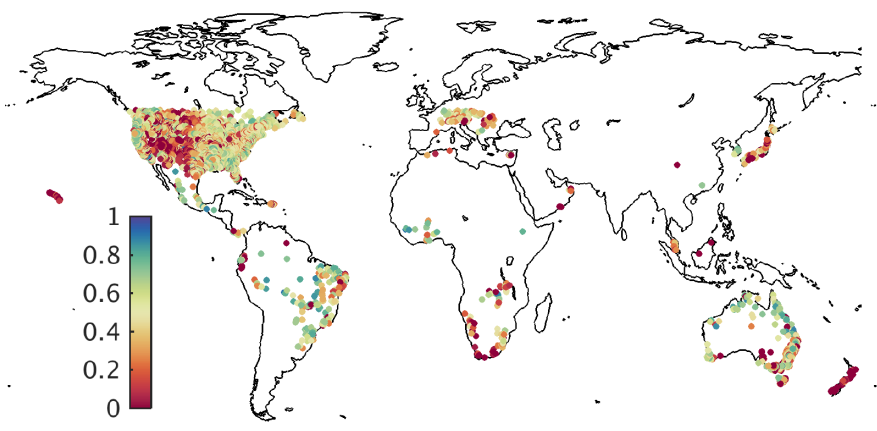

(c) CPC Unified

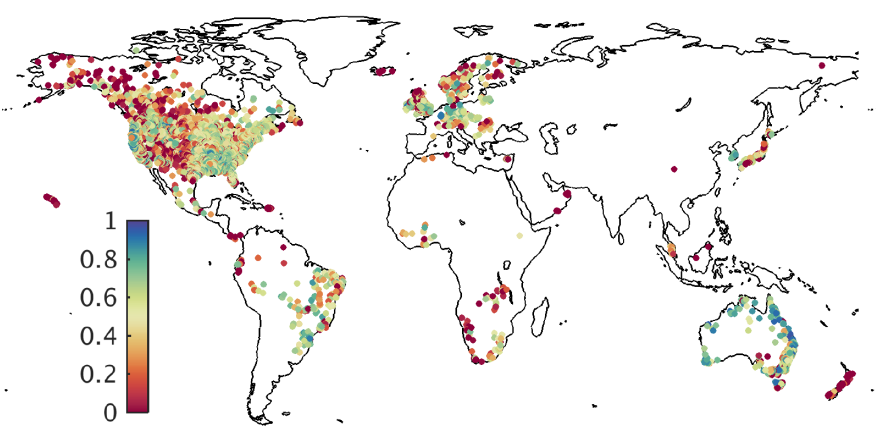

(e) MSWEP V2.0

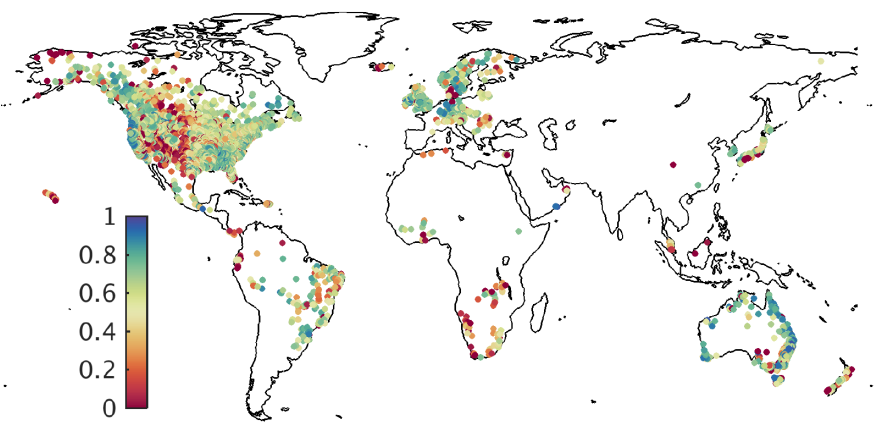

(g) TMPA 3B42 V7

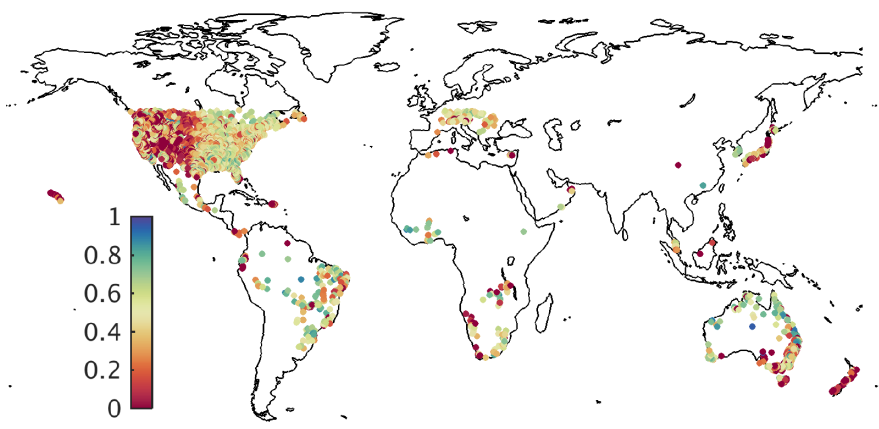

(b) CMORPH-CRT V1.0

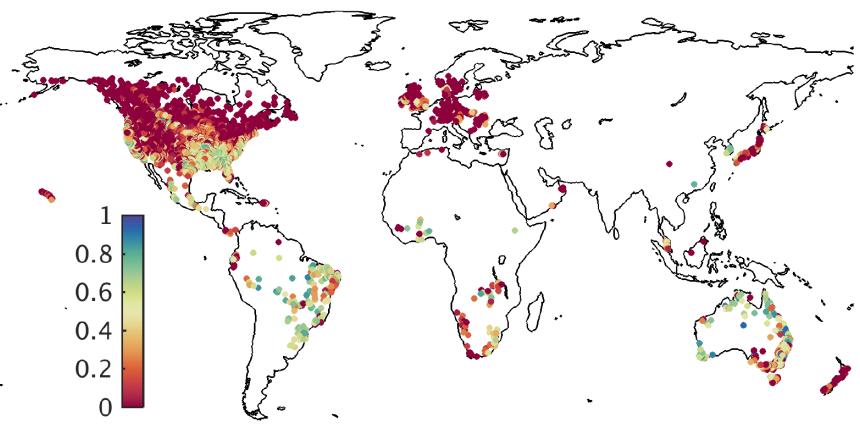

(d) MSWEP V1.2

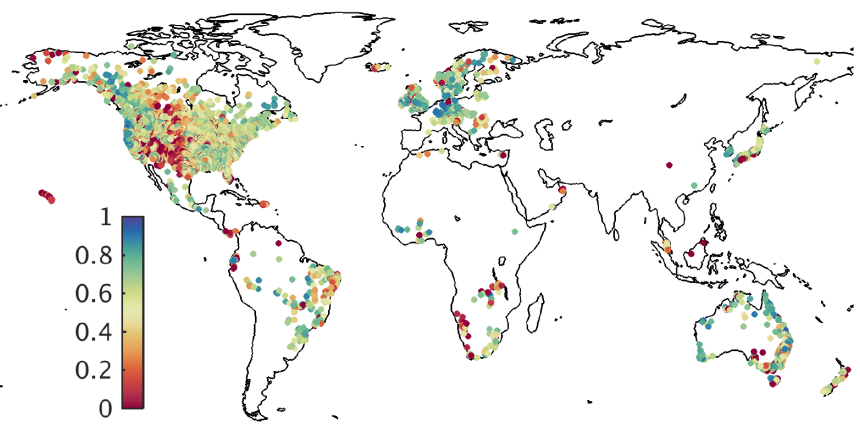

(f) PERSIANN-CDR V1R1

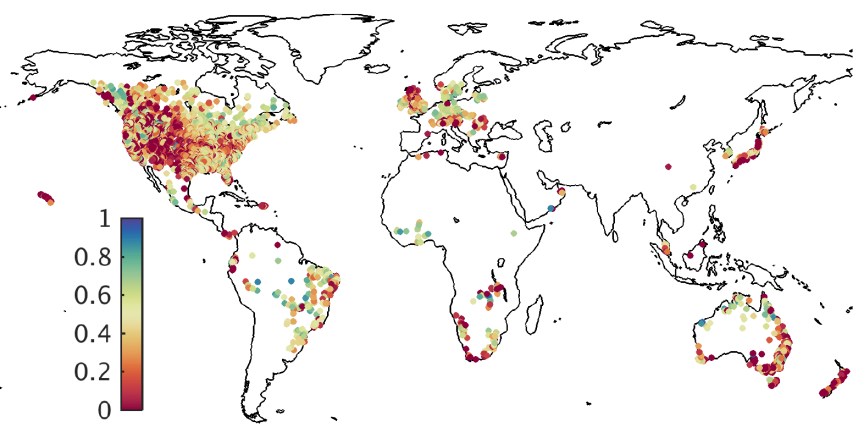

(h) WFDEI-CRU

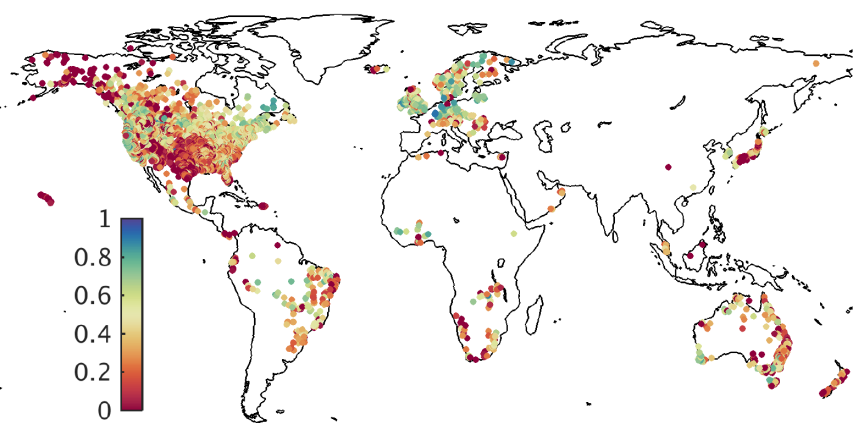

Figure 2. Calibration NSE scores obtained using $P$ time series from (a) CHIRPS V2.0, (b) CMORPH-CRT V1.0, (c) CPC Unified, (d) MSWEP V1.2, (e) MSWEP V2.0, (f) PERSIANN-CDR V1R1, (g) TMPA 3B42 V7, and (h) WFDEI-CRU. Each data point represents a catchment centroid. Only the eight best performing $P$ datasets are shown. 
Table 3. Median calibration NSE scores for the gauge-corrected $P$ datasets obtained using HBV. Only the catchments with calibration NSE values for all $P$ datasets are considered. Thus, catchments at latitudes $>50^{\circ}$ have been excluded. The results are grouped according to the five broadest Köppen-Geiger climate categories, commonly referred to using the letters A-E. Values in bold represent the highest score in each group.

\begin{tabular}{|c|c|c|c|c|c|c|c|c|c|c|}
\hline $\begin{array}{l}\text { Köppen-Geiger } \\
\text { climate zone }\end{array}$ & $\begin{array}{l}\text { Number of } \\
\text { catchments }\end{array}$ & $\begin{array}{r}\text { CHIRPS } \\
\text { V2.0 }\end{array}$ & $\begin{array}{r}\text { CMORPH-CRT } \\
\mathrm{V} 1.0\end{array}$ & $\begin{array}{r}\text { CPC } \\
\text { Unified }\end{array}$ & $\begin{array}{r}\text { GPCP-1DD } \\
\text { V1.2 }\end{array}$ & $\begin{array}{r}\text { MSWEP } \\
\text { V1.2 }\end{array}$ & $\begin{array}{r}\text { MSWEP } \\
\text { V2.0 }\end{array}$ & $\begin{array}{r}\text { PERSIANN-CDR } \\
\text { V1R1 }\end{array}$ & $\begin{array}{r}\text { TMPA 3B42 } \\
\text { V7 }\end{array}$ & WFDEI-CRU \\
\hline All & 8220 & 0.45 & 0.17 & 0.54 & 0.27 & 0.58 & 0.62 & 0.31 & 0.41 & 0.35 \\
\hline Tropical (A) & 289 & 0.40 & 0.31 & 0.25 & 0.22 & 0.43 & 0.53 & 0.26 & 0.31 & 0.13 \\
\hline Dry (B) & 384 & 0.17 & 0.12 & 0.23 & 0.12 & 0.25 & 0.26 & 0.12 & 0.18 & 0.17 \\
\hline Temperate (C) & 3491 & 0.48 & 0.44 & 0.59 & 0.27 & 0.60 & 0.67 & 0.30 & 0.45 & 0.30 \\
\hline Cold (D) & 4041 & 0.44 & -0.05 & 0.53 & 0.28 & 0.58 & 0.61 & 0.33 & 0.39 & 0.42 \\
\hline Polar (E) & 14 & 0.17 & -2.62 & -0.14 & 0.23 & 0.52 & 0.42 & 0.19 & 0.17 & 0.32 \\
\hline
\end{tabular}

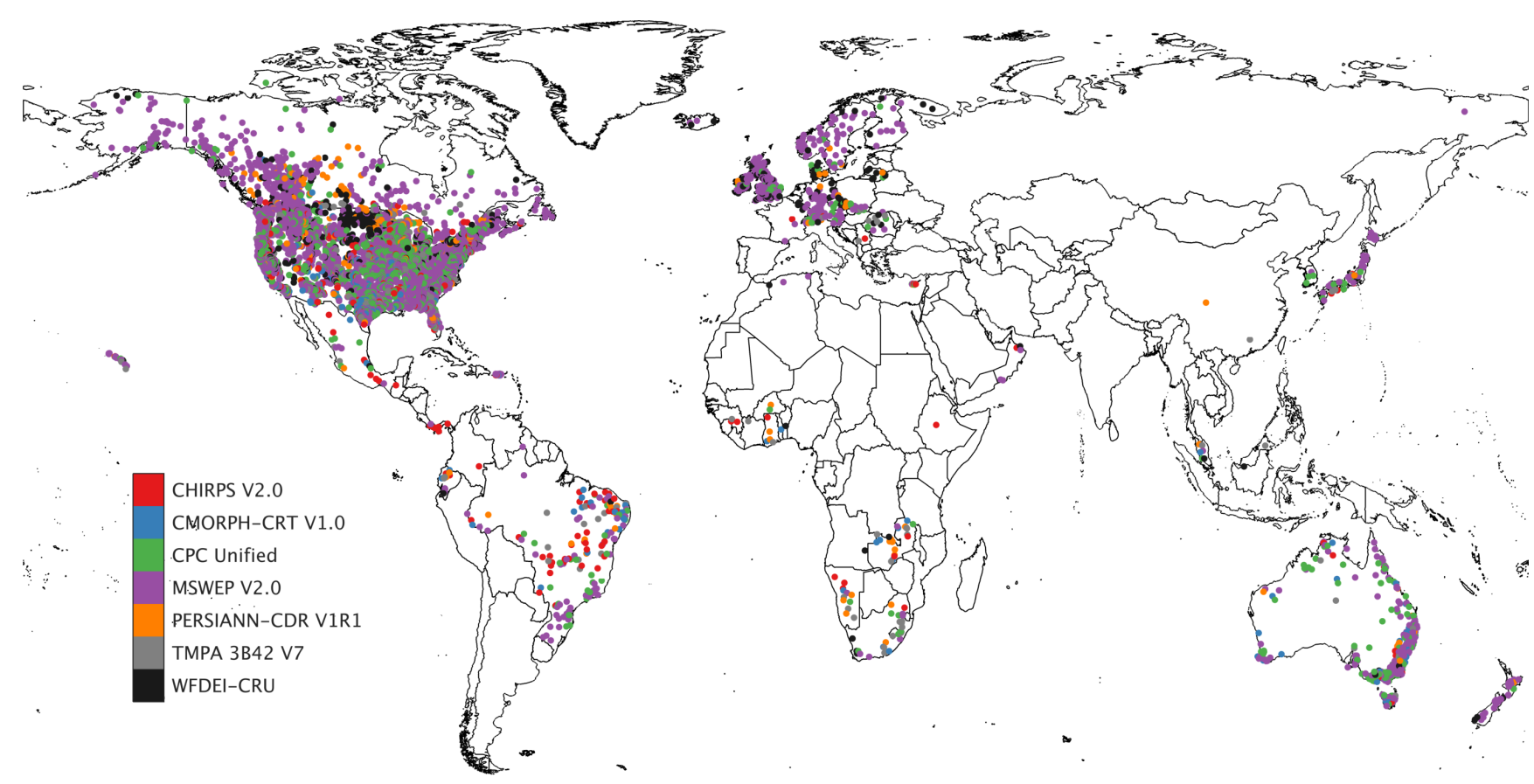

Figure 3. For each catchment, the $P$ dataset with the highest calibration NSE. Each data point represents a catchment centroid. Only the seven best performing $P$ datasets (excluding MSWEP V1.2 due to its similarity to V2.0) are considered. Note that CHIRPS V2.0, CMORPHCRT V1.0, PERSIANN-CDR V1R1, and TMPA 3B42 V7 do not provide data beyond 50, 60, 60, and 50 latitude, respectively.

best temporal correlations overall. They were followed, in order, by reanalyses, estimates based on microwave remote sensing of rainfall and near-surface soil moisture, and estimates based on thermal IR remote sensing. MSWEP-ng V2.0 obtained considerably lower mean annual $P$ trend errors than the other datasets. Contrary to expectations, two of the three reanalyses (ERAInterim and JRA-55) provided, on average, more reliable mean annual $P$ trends than the satellite datasets.

2. Among the uncorrected $P$ datasets, CHIRP V2.0 and MSWEP-ng V1.2 and V2.0 yielded the most accurate long-term $P$ means, primarily due to the use of highresolution gauge-based climatic datasets to determine their long-term mean. The reanalyses also provided reasonably accurate long-term means. The uncertainty in long-term means among the datasets was generally greatest in topographically complex and arid regions. In terms of the annual number of dry days, MSWEPng V2.0 exhibited markedly better performance than the other datasets, due to the use of CDF corrections after data merging. The satellite datasets also performed quite well in this respect, while CHIRP V2.0, the reanalyses, MSWEP-ng V1.2, and the soil moisture remote sensing-based SM2RAIN-ASCAT consistently underestimated the number of dry days. The satellite-based datasets generally exhibited difficulties in detecting $P$ signals at high latitudes.

3. Among the gauge-corrected $P$ datasets, the datasets directly incorporating daily gauge data (CPC Unified and the MSWEP versions) outperformed those directly in- 
corporating temporally coarser gauge data. These in turn outperformed the datasets that only indirectly incorporated gauge data. This highlights the benefit of explicit and careful incorporation of daily gauge data. The good performance of the fully gauge-based CPC Unified is unlikely to generalize to sparse or ungauged regions. In general, the performance was best in temperate regions, due to the presence of dense monitoring networks, and worst in arid regions, due to the convective rainfall and the highly non-linear rainfall-runoff response.

So, which $P$ dataset should one use? While this depends on the region under consideration and the specific user needs or application, in most cases MSWEP V2.0 appears to be a good choice: it has a long temporal record (1979-2016), a fully global coverage (including ocean areas), a comparatively high temporal (3-hourly) and spatial $\left(0.1^{\circ}\right)$ resolution, daily gauge corrections, and, as demonstrated in the current study, comparatively good performance for all performance metrics for all climate types. However, for tropical regions, CHIRPS V2.0 also presents a viable choice, if a daily temporal resolution suffices, and if the peak magnitude underestimation and spurious drizzle are less critical. In regions with dense rain gauge networks, CPC Unified also offers good performance. For some regions, notably Africa, it remains difficult to provide reliable recommendations due to the limited availability and quality of rain gauge and $Q$ data, highlighting the critical importance of maintaining and expanding data collection efforts.

Data availability. The $P$ datasets evaluated in this study are freely available via the respective URLs provided in Table 1.

\section{The Supplement related to this article is available online at https://doi.org/10.5194/hess-21-6201-2017- supplement.}

Competing interests. The authors declare that they have no conflict of interest.

Acknowledgements. We gratefully acknowledge the $P$ dataset developers for producing and making available their datasets. The Water Center for Arid and Semi-Arid Zones in Latin America and the Caribbean (CAZALAC) and the Centro de Ciencia del Clima y la Resiliencia (CR)2 (FONDAP 15110009) are thanked for sharing the Mexican and Chilean gauge data, respectively. We also acknowledge the gauge data providers in the Latin American Climate Assessment \& Dataset (LACA\&D) project: IDEAM (Colombia), INAMEH (Venezuela), INAMHI (Ecuador), SENAMHI (Peru), SENAMHI (Bolivia), and DMC (Chile). We further wish to thank Ali Alijanian, Koen Verbist, and Piyush Jain for providing additional gauge data. The Global Runoff Data Centre
(GRDC) and the United States Geological Survey (USGS) are gratefully acknowledged for providing the majority of the observed $Q$ data. We thank Mauricio Zambrano Bigiarini, Pete Peterson, Hamed Ashouri, Tomoo Ushio, and three anonymous reviewers for thoughtful comments and suggestions which helped improve the quality of the paper. Graham P. Weedon was supported by the Joint DECC and Defra Integrated Climate Program - DECC/Defra (GA01101). Vincenzo Levizzani wishes to acknowledge funding from the European Union Seventh Framework Programme (FP7/2007-2013) under grant agreement no. 603608, "Global Earth Observation for integrated water resource assessment": eartH2Observe, and from the "Progetto di Interesse NextData" of the Italian Ministry of Education, University, and Research (MIUR). The work was supported through IPA support for the first author from the U.S. Army Corps of Engineers' International Center for Integrated Water Resources Management (ICIWaRM), under the auspices of UNESCO, to further develop a Latin American and Caribbean drought monitor.

Edited by: Louise Slater

Reviewed by: three anonymous referees

\section{References}

Adler, R. F., Kidd, C., Petty, G., Morissey, M., and Goodman, H. M.: Intercomparison of global precipitation products: The third precipitation intercomparison project (PIP-3), B. Am. Meteorol. Soc., 82, 1377-1396, 2001.

AghaKouchak, A., Behrangi, A., Sorooshian, S., Hsu, K., and Amitai, E.: Evaluation of satellite-retrieved extreme precipitation rates across the central United States, J. Geophys. Res., 116, D02115, https://doi.org/10.1029/2010JD014741, 2011.

Akinremi, O. O., McGinn, S. M., and Cutforth, H. W.: Precipitation trends on the Canadian prairies, J. Climate, 12, 2996-3003, 1999.

Albergel, C., Dorigo, W., Reichle, R. H., Balsamo, G., de Rosnay, P., Muñoz Sabater, J. M., Isaksen, L., de Jeu, R., and Wagner, W.: Skill and global trend analysis of soil moisture from reanalyses and microwave remote sensing, J. Hydrometeorol., 14, 12591277, 2013.

Alijanian, M., Rakhshandehroo, G. R., Mishra, A. K., and Dehghani, M.: Evaluation of satellite rainfall climatology using CMORPH, PERSIANN-CDR, PERSIANN, TRMM, MSWEP over Iran, Int. J. Climatol., 37, 4896-4914, 2017.

Andréassian, V., Lerat, J., Loumagne, C., Mathevet, T., Michel, C., Oudin, L., and Perrin, C.: What is really undermining hydrologic science today?, Hydrol. Process., 21, 2819-2822, 2007.

Arakawa, A.: The cumulus parameterization problem: past, present, and future, J. Climate, 17, 2493-2525, 2004.

Ashlock, D.: Evolutionary computation for modeling and optimization, Springer Publishing Company, New York, 2010.

Ashouri, H., Hsu, K., Sorooshian, S., Braithwaite, D. K., Knapp, K. R., Cecil, L. D., Nelson, B. R., and Pratt, O. P.: PERSIANNCDR: daily precipitation climate data record from multisatellite observations for hydrological and climate studies, B. Am. Meteorol. Soc., 96, 69-83, 2015.

Ashouri, H., Nguyen, P., Thorstensen, A., Hsu, K., Sorooshian, S., and Braithwaite, D.: Assessing the efficacy of high-resolution 
satellite-based PERSIANN-CDR precipitation product in simulating streamflow, J. Hydrometeorol., 17, 2061-2076, 2016.

Barrett, E. C., Adler, R. F., Arpe, K., Bauer, P., Berg, W., Chang, A., Ferraro, R., Ferriday, J., Goodman, S., Hong, Y., Janowiak, J., Kidd, C., Kniveton, D., Morrissey, M., Olson, W., Petty, G., Rudolf, B., Shibata, A., Smith, E., and Spencer, R.: The first WetNet precipitation intercomparison project (PIP-1): Interpretation of results, Remote Sensing Reviews, 11, 303-373, https://doi.org/10.1080/02757259409532268, 1994

Beck, H. E.: MSWEP Version 2 documentation, Tech. rep., Princeton University, www.gloh2o.org, last access: August 2017.

Beck, H. E., Bruijnzeel, L. A., van Dijk, A. I. J. M., McVicar, T. R., Scatena, F. N., and Schellekens, J.: The impact of forest regeneration on streamflow in 12 mesoscale humid tropical catchments, Hydrol. Earth Syst. Sci., 17, 2613-2635, https://doi.org/10.5194/hess-17-2613-2013, 2013.

Beck, H. E., van Dijk, A. I. J. M., and de Roo, A.: Global maps of streamflow characteristics based on observations from several thousand catchments, J. Hydrometeorol., 16, 1478-1501, 2015.

Beck, H. E., van Dijk, A. I. J. M., de Roo, A., Miralles, D. G., McVicar, T. R., Schellekens, J., and Bruijnzeel, L. A.: Global-scale regionalization of hydrologic model parameters, Water Resour. Res., 52, 3599-3622, https://doi.org/10.1002/2015WR018247, 2016.

Beck, H. E., van Dijk, A. I. J. M., Levizzani, V., Schellekens, J., Miralles, D. G., Martens, B., and de Roo, A.: MSWEP: 3hourly $0.25^{\circ}$ global gridded precipitation (1979-2015) by merging gauge, satellite, and reanalysis data, Hydrol. Earth Syst. Sci., 21, 589-615, https://doi.org/10.5194/hess-21-589-2017, 2017a.

Beck, H. E., van Dijk, A. I. J. M., de Roo, A., Dutra, E., Fink, G., Orth, R., and Schellekens, J.: Global evaluation of runoff from 10 state-of-the-art hydrological models, Hydrol. Earth Syst. Sci., 21, 2881-2903, https://doi.org/10.5194/hess-21-2881-2017, 2017 b.

Behrangi, A., Khakbaz, B., Jaw, T. C., AghaKouchak, A., Hsu, K., and Sorooshian, S.: Hydrologic evaluation of satellite precipitation products over a mid-size basin, J. Hydrol., 397, 225-237, 2011.

Bengtsson, L., Hagemann, S., and Hodges, K. I.: Can climate trends be calculated from reanalysis data?, J. Geophys. Res., 109, D11111, https://doi.org/10.1029/2004JD004536, 2004.

Bergström, S.: The HBV model - its structure and applications, SMHI Reports RH 4, Swedish Meteorological and Hydrological Institute (SMHI), Norrköping, Sweden, 1992.

Bitew, M. M., Gebremichael, M., Ghebremichael, L. T., and Bayissa, Y. A.: Evaluation of high-resolution satellite rainfall products through streamflow simulation in a hydrological modeling of a small mountainous watershed in Ethiopia, J. Hydrometeorol., 13, 338-350, 2012.

Bock, A. R., Hay, L. E., McCabe, G. J., Markstrom, S. L., and Atkinson, R. D.: Parameter regionalization of a monthly water balance model for the conterminous United States, Hydrol. Earth Syst. Sci., 20, 2861-2876, https://doi.org/10.5194/hess-20-28612016, 2016.

Bosilovich, M. G., Chen, J., Robertson, F. R., and Adler, R. F.: Evaluation of global precipitation in reanalyses, J. Appl. Meteorol. Clim., 47, 2279-2299, 2008.

Brocca, L., Ciabatta, L., Massari, C., Moramarco, T., Hahn, S., Hasenauer, S., Kidd, R., Dorigo, W., Wagner, W., and Levizzani, V.: Soil as a natural rain gauge: estimating global rainfall from satellite soil moisture data, J. Geophys. Res.-Atmos., 119, 51285141, 2014.

Buarque, D. C., de Paiva, R. C. D., Clarke, R. T., and Mendes, C. A. B.: A comparison of Amazon rainfall characteristics derived from TRMM, CMORPH and the Brazilian national rain gauge network, J. Geophys. Res., 116, D19105, https://doi.org/10.1029/2011JD016060, 2011.

Bumke, K., König-Langlo, G., Kinzel, J., and Schröder, M.: HOAPS and ERA-Interim precipitation over the sea: validation against shipboard in situ measurements, Atmos. Meas. Tech., 9, 2409-2423, https://doi.org/10.5194/amt-9-2409-2016, 2016.

Cattani, E., Merino, A., and Levizzani, V.: Evaluation of monthly satellite-derived precipitation products over East Africa, J. Hydrometeorol., 17, 2555-2573, 2016.

Cecil, D. J., Buechler, D. E., and Blakeslee, R. J.: Gridded lightning climatology from TRMM-LIS and OTD: Dataset description, Atmos. Res., 135, 404-414, https://doi.org/10.1016/j.atmosres.2012.06.028, 2014.

Chai, T. and Draxler, R. R.: Root mean square error (RMSE) or mean absolute error (MAE)? - Arguments against avoiding RMSE in the literature, Geosci. Model Dev., 7, 1247-1250, https://doi.org/10.5194/gmd-7-1247-2014, 2014.

Chen, M., Shi, W., Xie, P., Silva, V. B. S., Kousky, V. E., Higgins, R. W., and Janowiak, J. E.: Assessing objective techniques for gauge-based analyses of global daily precipitation, J. Geophys. Res., 113, D04110, https://doi.org/10.1029/2007JD009132, 2008.

Chen, S., Hong, Y., Gourley, J. J., Huffman, G. J., Tian, Y., Cao, Q., Yong, B., Kirstetter, P.-E., Hu, J., Hardy, J., Li, Z., Khan, S. I., and Xue, X.: Evaluation of the successive V6 and V7 TRMM multisatellite precipitation analysis over the Continental United States, Water Resources Research, 49, 8174-8186, 2013.

Ciabatta, L., Massari, C., Brocca, L., Gruber, A., Reimer, C., Hahn, S., Paulik, C., Dorigo, W., Kidd, R., and Wagner, W.: SM2RAIN-CCI: A new global long-term rainfall data set derived from ESA CCI soil moisture, Earth Syst. Sci. Data Discuss., https://doi.org/10.5194/essd-2017-86, in review, 2017.

Clark, P., Roberts, N., Lean, H., Ballard, S. P., and Charlton-Perez, C.: Convection-permitting models: a step-change in rainfall forecasting, Meteorol. Appl., 23, 165-181, 2016.

Collischonn, B., Collischonn, W., and Tucci, C. E. M.: Daily hydrological modeling in the Amazon basin using TRMM rainfall estimates, J. Hydrol., 360, 207-216, 2008.

Criss, R. E. and Winston, W. E.: Do Nash values have value? Discussion and alternate proposals, Hydrol. Process., 22, 2723 2725, 2008.

Crow, W. T., van den Berg, M. J., Huffman, G. J., and Pellarin, T.: Correcting rainfall using satellite-based surface soil moisture retrievals: The Soil Moisture Analysis Rainfall Tool (SMART), Water Resour. Res., 47, W08521, https://doi.org/10.1029/2011WR010576, 2011.

Daly, C., Halbleib, M., Smith, J. I., Gibson, W. P., Doggett, M. K., Taylor, G. H., Curtis, J., and Pasteris, P. P.: Physiographically sensitive mapping of climatological temperature and precipitation across the conterminous United States, Int. J. Climatol., 28, 2031-2064, 2008.

Dee, D. P., Uppala, S. M., Simmons, A. J., Berrisford, P., Poli, P., Kobayashi, S., Andrae, U., Balmaseda, M. A., Balsamo, G., Bauer, P., Bechtold, P., Beljaars, A. C. M., van de Berg, L., Bid- 
lot, J., Bormann, N., Delsol, C., Dragani, R., Fuentes, M., Geer, A. J., Haimberger, L., Healy, S. B., Hersbach, H., Hólm, E. V., Isaksen, L., Kallberg, P., Köhler, M., Matricardi, M., McNally, A. P., Monge-Sanz, B. M., Morcrette, J.-J., Park, B.-K., Peubey, C., de Rosnay, P., Tavolato, C., Thépaut, J.-N., and Vitart, F.: The ERA-Interim reanalysis: configuration and performance of the data assimilation system, Q. J. Roy. Meteor. Soc., 137, 553-597, 2011.

Deelstra, J., Farkas, C., Engebretsen, A., Kværnø, S., Beldring, S., Olszewska, A., and Nesheim, L.: Can we simulate runoff from agriculture dominated watersheds? Comparison of the DrainMod, SWAT, HBV, COUP and INCA models applied for the Skuterud catchment, Bioforsk FOKUS, 5, 119-128, 2010.

Di Giuseppe, F., Molteni, F., and Dutra, E.: Real-time correction of ERA-Interim monthly rainfall, Geophys. Res. Lett., 40, 37503755, 2013.

Dinku, T., Ceccato, P., and Connor, S. J.: Challenges of satellite rainfall estimation over mountainous and arid parts of east Africa, Int. J. Remote Sens., 32, 5965-5979, 2016.

Driouech, F., Déqué, M., and Mokssit, A.: Numerical simulation of the probability distribution function of precipitation over Morocco, Clim. Dynam., 32, 1055-1063, 2009.

Ebert, E. E.: Methods for Verifying Satellite Precipitation Estimates, in: Measuring Precipitation From Space, edited by: Levizzani, V., Bauer, P., and Turk, F. J., Advances In Global Change Research, Springer, Dordrecht, 28, 345-356, 2007.

Ebert, E. E., Janowiak, J. E., and Kidd, C.: Comparison of nearreal-time precipitation estimates from satellite observations and numerical models, B. Am. Meteorol. Soc., 88, 47-64, 2007.

Essou, G. R. C., Arsenault, R., and Brissette, F. P.: Comparison of climate datasets for lumped hydrological modeling over the continental United States, J. Hydrol., 537, 334-345, https://doi.org/10.1016/j.jhydrol.2016.03.063, 2016.

Falck, A. S., Maggioni, V., Tomasella, J., Vila, D. A., and Diniz, F. L. R.: Propagation of satellite precipitation uncertainties through a distributed hydrologic model: A case study in the Tocantins-Araguaia basin in Brazil, J. Hydrol., 527, 943-957, https://doi.org/10.1016/j.jhydrol.2015.05.042, 2015.

Falcone, J. A., Carlisle, D. M., Wolock, D. M., and Meador, M. R.: GAGES: A stream gage database for evaluating natural and altered flow conditions in the conterminous United States, Ecology, 91, 621, https://doi.org/10.1890/09-0889.1, 2010.

Fekete, B. M., Vörösmarty, C. J., Roads, J. O., and Willmott, C. J.: Uncertainties in precipitation and their impacts on runoff estimates, J. Climate, 17, 294-304, 2004.

Ferraro, R. R., Smith, E. A., Berg, W., and Huffman, G. J.: A screening methodology for passive microwave precipitation retrieval algorithms, J. Atmos. Sci., 55, 1583-1600, 1998.

Fick, S. E. and Hijmans, R. J.: WorldClim 2: new 1-km spatial resolution climate surfaces for global land areas, Int. J. Climatol., 37, 4302-4315, https://doi.org/10.1002/joc.5086, 2017.

Fortin, F., De Rainville, F., Gardner, M., Parizeau, M., and Gagné, C.: DEAP: evolutionary algorithms made easy, J. Mach. Learn. Res., 13, 2171-2175, 2012.

Funk, C., Peterson, P., Landsfeld, M., Pedreros, D., Verdin, J., Shukla, S., Husak, G., Rowland, J., Harrison, L., Hoell, A., and Michaelsen, J.: The climate hazards infrared precipitation with stations - a new environmental record for monitoring extremes, Scientific Data, 2, 150066, https://doi.org/10.1038/sdata.2015.66, 2015a.

Funk, C., Verdin, A., Michaelsen, J., Peterson, P., Pedreros, D., and Husak, G.: A global satellite-assisted precipitation climatology, Earth Syst. Sci. Data, 7, 275-287, https://doi.org/10.5194/essd7-275-2015, 2015b.

Garrison, G. H., Glenn, C. R., and McMurtry, G. M.: Measurement of submarine groundwater discharge in Kahana Bay, Oahu, Hawaii, Limnol. Oceanogr., 48, 920-928, 2003.

Gebremichael, M.: Framework for satellite rainfall product evaluation, in: Rainfall: State of the Science, edited by Testik, F. Y. and Gebremichael, M., Geophysical Monograph Series, American Geophysical Union, Washington, D. C., https://doi.org/10.1029/2010GM000974, 2010.

Gehne, M., Hamill, T. M., Kiladis, G. N., and Trenberth, K. E.: Comparison of global precipitation estimates across a range of temporal and spatial scales, J. Climate, 29, 7773-7795, 2016.

Groisman, P. Y. and Legates, D. R.: The accuracy of United States precipitation data, B. Am. Meteorol. Soc., 72, 215-227, 1994.

Gupta, H. V., Kling, H., Yilmaz, K. K., and Martinez, G. F.: Decomposition of the mean squared error and NSE performance criteria: Implications for improving hydrological modelling, J. Hydrol., 370, 80-91, 2009.

Gupta, H. V., Perrin, C., Blöschl, G., Montanari, A., Kumar, R., Clark, M., and Andréassian, V.: Large-sample hydrology: a need to balance depth with breadth, Hydrol. Earth Syst. Sci., 18, 463477, https://doi.org/10.5194/hess-18-463-2014, 2014.

Haiden, T., Rodwell, M. J., Richardson, D. S., Okagaki, A., Robinson, T., and Hewson, T.: Intercomparison of global model precipitation forecast skill in 2010/11 using the SEEPS Score, Mon. Weather Rev., 140, 2720-2733, 2012.

Hayes, M. J., Svoboda, M. D., Wilhite, D. A., and Vanyarkho, O. V.: Monitoring the 1996 drought using the Standardized Precipitation Index, B. Am. Meteorol. Soc., 80, 429-438, 1999.

Haylock, M. R., Hofstra, N., Klein Tank, A. M. G., Klok, E. J., Jones, P., and New, M.: A European daily highresolution gridded data set of surface temperature and precipitation for 1950-2006, J. Geophys. Res., 113, D20119, https://doi.org/10.1029/2008JD010201, 2008.

Herold, N., Alexander, L. V., Donat, M. G., Contractor, S., and Becker, A.: How much does it rain over land?, Geophys. Res. Lett., 43, 341-348, 2015.

Hirpa, F. A., Gebremichael, M., and Hopson, T.: Evaluation of highresolution satellite precipitation products over very complex terrain in Ethiopia, J. Appl. Meteorol. Clim., 49, 1044-1051, 2010.

Hong, Y., Hsu, K.-L., Sorooshian, S., and Gao, X.: Precipitation Estimation from Remotely Sensed Imagery Using an Artificial Neural Network Cloud Classification System, J. Appl. Meteorol., 43, 1834-1853, 2004.

Huffman, G. J., Adler, R. F., Morrissey, M. M., Bolvin, D. T., Curtis, S., Joyce, R., McGavock, B., and Susskind, J.: Global precipitation at one-degree daily resolution from multi-satellite observations, J. Hydrometeorol., 2, 36-50, 2001.

Huffman, G. J., Bolvin, D. T., Nelkin, E. J., Wolff, D. B., Adler, R. F., Gu, G., Hong, Y., Bowman, K. P., and Stocker, E. F.: The TRMM Multisatellite Precipitation Analysis (TMPA): quasiglobal, multiyear, combined-sensor precipitation estimates at fine scales, J. Hydrometeorol., 8, 38-55, 2007. 
Islam, T., Rico-Ramirez, M. A., Han, D., Srivastava, P. K., and Ishak, A. M.: Performance evaluation of the TRMM precipitation estimation using ground-based radars from the GPM validation network, J. Atmos. Sol.-Terr. Phy., 77, 194-208, https://doi.org/10.1016/j.jastp.2012.01.001, 2012.

Jain, S. K. and Sudheer, K. P.: Fitting of hydrologic models: a close look at the Nash-Sutcliffe index, J. Hydrol. Eng., 13, 981-986, 2008.

Joyce, R. J., Janowiak, J. E., Arkin, P. A., and Xi, P.: CMORPH: A method that produces global precipitation estimates from passive microwave and infrared data at high spatial and temporal resolution, J. Hydrometeorol., 5, 487-503, 2004.

Kang, S. and Ahn, J.-B.: Global energy and water balances in the latest reanalyses, Asia-Pac. J. Atmos. Sci., 51, 293-302, 2015.

Kauffeldt, A., Halldin, S., Rodhe, A., Xu, C.-Y., and Westerberg, I. K.: Disinformative data in large-scale hydrological modelling, Hydrol. Earth Syst. Sci., 17, 2845-2857, https://doi.org/10.5194/hess-17-2845-2013, 2013.

Kidd, C. and Levizzani, V.: Status of satellite precipitation retrievals, Hydrol. Earth Syst. Sci., 15, 1109-1116, https://doi.org/10.5194/hess-15-1109-2011, 2011.

Kidd, C., Bauer, P., Turk, J., Huffman, G. J., Joyce, R., Hsu, K.-L., and Braithwaite, D.: Intercomparison of high-resolution precipitation products over northwest Europe, J. Hydrometeorol., 13, 67-83, 2012.

Kidd, C., Dawkins, E., and Huffman, G.: Comparison of precipitation derived from the ECMWF operational forecast model and satellite precipitation datasets, J. Hydrometeorol., 14, 14631482, 2013.

Kim, K., Park, J., Baik, J., and Choi, M.: Evaluation of topographical and seasonal feature using GPM IMERG and TRMM 3B42 over Far-East Asia, Atmos. Res., 187, 95-105, 2017.

Knapp, K. R., Ansari, S., Bain, C. L., Bourassa, M. A., Dickinson, M. J., Funk, C., Helms, C. N., Hennon, C. C., Holmes, C. D., Huffman, G. J., Kossin, J. P., Lee, H.-T., Loew, A., and Magnusdottir, G.: Globally gridded satellite observations for climate studies, B. Am. Meteorol. Soc., 92, 893-907, 2011.

Kobayashi, S., Ota, Y., Harada, Y., Ebita, A., Moriya, M., Onoda, H., Onogi, K., Kamahori, H., Kobayashi, C., Endo, H., Miyaoka, K., and Takahashi, K.: The JRA-55 reanalysis: General specifications and basic characteristics, J. Meteorol. Soc. Jpn. Ser. I, 93, 5-48, https://doi.org/10.2151/jmsj.2015-001, 2015.

Krause, P., Boyle, D. P., and Bäse, F.: Comparison of different efficiency criteria for hydrological model assessment, Adv. Geosci., 5, 89-97, https://doi.org/10.5194/adgeo-5-89-2005, 2005.

Laviola, S., Levizzani, V., Cattani, E., and Kidd, C.: The 183-WSL fast rainrate retrieval algorithm. Path II: Validation using ground radar measurements, Atmos. Res., 134, 77-86, 2013.

Li, L., Ngongondo, C. S., Xu, C.-Y., and Gong, L.: Comparison of the global TRMM and WFD precipitation datasets in driving a large-scale hydrological model in southern Africa, Hydrol. Res., 44, 770-788, 2013.

Loew, A., Bell, W., Brocca, L., Bulgin, C. E., Burdanowitz, J., Calbet, X., Donner, R. V., Ghent, D., Gruber, A., Kaminski, T., Kinzel, J., Klepp, C., Lambert, J.-C., Schaepman-Strub, H., and Schröder, M.: Validation practices for satellite based earth observation data across communities, Rev. Geophys., 55, 779-817, https://doi.org/10.1002/2017RG000562, 2017.
Lopez, P.: Cloud and precipitation parameterizations in modeling and variational data assimilation: a review, J. Atmos. Sci., 64, 3766-3784, 2007.

Lorenz, C. and Kunstmann, H.: The hydrological cycle in three state-of-the-art reanalyses: intercomparison and performance analysis, J. Hydrometeorol., 13, 1397-1420, 2012.

Maggioni, V., Meyers, P. C., and Robinson, M. D.: A review of merged high resolution satellite precipitation product accuracy during the Tropical Rainfall Measuring Mission (TRMM)-era, J. Hydrometeorol., 17, 1101-1117, https://doi.org/10.1175/JHM-D-15-0190.1, 2016.

Maraun, D.: Bias correction, quantile mapping, and downscaling: revisiting the inflation issue, J. Climate, 26, 2137-2143, 2013.

Martens, B., Miralles, D. G., Lievens, H., van der Schalie, R., de Jeu, R. A. M., Fernández-Prieto, D., Beck, H. E., Dorigo, W. A., and Verhoest, N. E. C.: GLEAM v3: satellite-based land evaporation and root-zone soil moisture, Geosci. Model Dev., 10, 1903-1925, https://doi.org/10.5194/gmd-10-1903-2017, 2017.

Massari, C., Crow, W., and Brocca, L.: An assessment of the performance of global rainfall estimates without groundbased observations, Hydrol. Earth Syst. Sci., 21, 4347-4361, https://doi.org/10.5194/hess-21-4347-2017, 2017.

Mei, Y., Anagnostou, E. N., Nikolopoulos, E. I., and Borga, M.: Error analysis of satellite precipitation products in mountainous basins, J. Hydrometeorol., 15, 1778-1793, 2014.

Menne, M. J., Durre, I., Vose, R. S., Gleason, B. E., and Houston, T. G.: An overview of the Global Historical Climatology Network-Daily database, J. Atmos. Ocean. Tech., 29, 897-910, 2012.

Michaelides, S., Levizzani, V., Anagnostou, E., Bauer, P., Kasparis, T., and Lane, J. E.: Precipitation: measurement, remote sensing, climatology and modeling, Atmos. Res., 94, 512-533, 2009.

Moazami, S., Golian, S., Kavianpour, M. R., and Hong, Y.: Comparison of PERSIANN and V7 TRMM Multi-satellite Precipitation Analysis (TMPA) products with rain gauge data over Iran, Int. J. Remote Sens., 34, 8156-8171, 2013.

Moriasi, D. N., Arnold, J. G., Van Liew, M. W., Bingner, R. L., Harmel, R. D., and Veith, T. L.: Model evaluation guidelines for systematic quantification of accuracy in watershed simulations, Transactions of the American Society of Agricultural and Biological Engineers, 50, 885-900, 2007.

Nair, A. S. and Indu, J.: Performance assessment of Multi-Source Weighted-Ensemble Precipitation (MSWEP) product over India, Climate, 5, 2, https://doi.org/10.3390/cli5010002, 2017.

Nash, J. E. and Sutcliffe, J. V.: River flow forecasting through conceptual models part I - a discussion of principles, J. Hydrol., 10, 282-290, 1970.

Newman, A. J., Clark, M. P., Sampson, K., Wood, A., Hay, L. E., Bock, A., Viger, R. J., Blodgett, D., Brekke, L., Arnold, J. R., Hopson, T., and Duan, Q.: Development of a large-sample watershed-scale hydrometeorological data set for the contiguous USA: data set characteristics and assessment of regional variability in hydrologic model performance, Hydrol. Earth Syst. Sci., 19, 209-223, https://doi.org/10.5194/hess-19-209-2015, 2015.

Pan, M., Li, H., and Wood, E.: Assessing the skill of satellite-based precipitation estimates in hydrologic applications, Water Resour. Res., 46, W09535, https://doi.org/10.1029/2009WR008290, 2010 . 
Peel, M. C., Chiew, F. H. S., Western, A. W., and McMahon, T. A.: Extension of unimpaired monthly streamflow data and regionalisation of parameter values to estimate streamflow in ungauged catchments, report prepared for the Australian National Land and Water Resources Audit, Centre for Environmental Applied Hydrology, University of Melbourne, Australia, 2000.

Peña Arancibia, J. L., van Dijk, A. I. J. M., Renzullo, L. J., and Mulligan, M.: Evaluation of precipitation estimation accuracy in reanalyses, satellite products, and an ensemble method for regions in Australia and Sout and East Asia, J. Hydrometeorol., 14, 1323-1333, 2013.

Pilgrim, D. H., Chapman, T. G., and Doran, D. G.: Problems of rainfall-runoff modelling in arid and semiarid regions, Hydrolog. Sci. J., 33, 379-400, 1988.

Plesca, I., Timbe, E., Exbrayat, J. F., Windhorst, D., Kraft, P., Crespo, P., Vachéa, K. B., Frede, H. G., and Breuer, L.: Model intercomparison to explore catchment functioning: Results from a remote montane tropical rainforest, Ecol. Model., 239, 3-13, 2012.

Prein, A. F., Langhans, W., Fosser, G., Ferrone, A., Ban, N., Goergen, K., Keller, M., Tölle, M., Gutjahr, O., Feser, F., Brisson, E., Kollet, S., Schmidli, J., van Lipzig, N. P. M., and Leung, R.: A review on regional convection-permitting climate modeling: demonstrations, prospects, and challenges, Rev. Geophys., 53, 323-361, 2015.

Rasmussen, R. M., Baker, B., Kochendorfer, J., Meyers, T., Landolt, S., Fischer, A. P., Black, J., Thériault, J. M., Kucera, P., Gochis, D., Smith, C., Nitu, R., Hall, M., Ikeda, K., and Gutmann, E.: How well are we measuring snow: The NOAA/FAA/NCAR winter precipitation test bed, B. Am. Meteorol. Soc., 93, 811-829, https://doi.org/10.1175/BAMS-D-11-00052.1, 2012.

Saha, S., Moorthi, S., Pan, H.-L., Wu, X., Wang, J., Nadiga, S., Tripp, P., Kistler, R., Woollen, J., Behringer, D., Liu, H., Stokes, D., Grumbine, R., Gayno, G., Wang, J., Hou, Y.-T., Chuang, H.Y., Juang, H.-M. H., Sela, J., Iredell, M., Treadon, R., Kleist, D., Van Delst, P., Keyser, D., Derber, J., Ek, M., Meng, J., Wei, H., Yang, R., Lord, S., Van Den Dool, H., Kumar, A., Wang, W., Long, C., Chelliah, M., Xue, Y., Huang, B., Schemm, J.-K., Ebisuzaki, W., Lin, R., Xie, P., Chen, M., Zhou, S., Higgins, W., Zou, C.-Z., Liu, Q., Chen, Y., Han, Y., Cucurull, L., Reynolds, R. W., Rutledge, G., and Goldberg, M.: The NCEP climate forecast system reanalysis, B. Am. Meteorol. Soc., 91, 1015-1057, 2010.

Schaefli, B. and Gupta, H. V.: Do Nash values have value?, Hydrol. Process., 21, 2075-2080, 2007.

Scheel, M. L. M., Rohrer, M., Huggel, Ch., Santos Villar, D., Silvestre, E., and Huffman, G. J.: Evaluation of TRMM Multisatellite Precipitation Analysis (TMPA) performance in the Central Andes region and its dependency on spatial and temporal resolution, Hydrol. Earth Syst. Sci., 15, 2649-2663, https://doi.org/10.5194/hess-15-2649-2011, 2011.

Schneider, U., Becker, A., Finger, P., Meyer-Christoffer, A., Ziese, M., and Rudolf, B.: GPCC's new land surface precipitation climatology based on quality-controlled in situ data and its role in quantifying the global water cycle, Theor. Appl. Climatol., 115, 15-40, 2014.

Seibert, J. and Vis, M. J. P.: Teaching hydrological modeling with a user-friendly catchment-runoff-model software package, Hydrol.
Earth Syst. Sci., 16, 3315-3325, https://doi.org/10.5194/hess-163315-2012, 2012.

Skok, G., Žagar, N., Honzak, L., Žabkar, R., Rakovec, J., and Ceglar, A.: Precipitation intercomparison of a set of satellite- and raingauge-derived datasets, ERA Interim reanalysis, and a single WRF regional climate simulation over Europe and the North Atlantic, Theor. Appl. Climatol., 123, 217-232, 2015.

Sorooshian, S., Hsu, K.-L., Gao, X., Gupta, H. V., Imam, B., and Braithwaite, D.: Evaluation of PERSIANN system satellitebased estimates of tropical rainfall, B. Am. Meteorol. Soc., 81, 2035-2046, 2000.

Stephens, G. L. and Kummerow, C. D.: The remote sensing of clouds and precipitation from space: a review, J. Atmos. Sci., 64, 3742-3765, 2007.

Stillman, S., Zeng, X., and Bosilovich, M. G.: Evaluation of 22 precipitation and 23 soil moisture products over a semiarid area in southeastern Arizona, J. Hydrometeorol., 17, 211-230, 2016.

Su, F., Hong, Y., and Lettenmaier, D. P.: Evaluation of TRMM Multisatellite Precipitation Analysis (TMPA) and its utility in hydrologic prediction in the La Plata Basin, J. Hydrometeorol., 9, 622, 2008.

Sun, Y., Solomon, S., Dai, A., and Portmann, R. W.: How often does it rain?, J. Climate, 19, 916-934, 2006.

Sylla, M. B., Giorgi, F., Coppola, E., and Mariotti, L.: Uncertainties in daily rainfall over Africa: assessment of gridded observation products and evaluation of a regional climate model simulation, Int. J. Climatol., 33, 1805-1817, 2013.

Tang, G., Zeng, Z., Long, D., Guo, X., Yong, B., Zhang, W., and Hong, Y.: Statistical and hydrological comparisons between TRMM and GPM Level-3 products over a midlatitude basin: Is day-1 IMERG a good successor for TMPA 3B42V7?, J. Hydrometeorol., 17, 121-137, 2016.

Tapiador, F. J., Turk, F. J., Petersen, W., Hou, A. Y., García-Ortega, E., Machado, L. A. T., Angelis, C. F., Salio, P., Kidd, C., Huffman, G. J., and de Castro, M.: Global precipitation measurement: Methods, datasets and applications, Atmos. Res., 104-105, 7097, 2012.

te Linde, A. H., Aerts, J. C. J. H., Hurkmans, R. T. W. L., and Eberle, M.: Comparing model performance of two rainfallrunoff models in the Rhine basin using different atmospheric forcing data sets, Hydrol. Earth Syst. Sci., 12, 943-957, https://doi.org/10.5194/hess-12-943-2008, 2008.

Tian, Y. and Peters-Lidard, C. D.: A global map of uncertainties in satellite-based precipitation measurements, Geophys. Res. Lett., 37, L24407, https://doi.org/10.1029/2010GL046008, 2010.

Ushio, T., Kubota, T., Shige, S., Okamoto, K., Aonashi, K., Inoue, T., Takahashi, N., Iguchi, T., Kachi, M., Oki, R., Morimoto, T., and Kawasaki, Z.: A Kalman filter approach to the Global Satellite Mapping of Precipitation (GSMaP) from combined passive microwave and infrared radiometric data, J. Meteorol. Soc. Jpn., 87A, 137-151, 2009.

Valéry, A., Andréassian, V., and Perrin, C.: "As simple as possible but not simpler": What is useful in a temperature-based snowaccounting routine? Part 1 - Comparison of six snow accounting routines on 380 catchments, J. Hydrol., 517, 1166-1175, https://doi.org/10.1016/j.jhydrol.2014.04.059, 2014.

Vetter, T., Huang, S., Aich, V., Yang, T., Wang, X., Krysanova, V., and Hattermann, F.: Multi-model climate impact assessment and intercomparison for three large-scale river basins on three conti- 
nents, Earth Syst. Dynam., 6, 17-43, https://doi.org/10.5194/esd6-17-2015, 2015.

Vila, D. A., de Goncalves, L. G. G., Toll, D. L., and Rozante, J. R.: Statistical evaluation of combined daily gauge observations and rainfall satellite estimates over continental South America, J. Hydrometeorol., 10, 533-543, 2009.

Voisin, N., Wood, A. W., and Lettenmaier, D. P.: Evaluation of precipitation products for global hydrological prediction, J. Hydrometeorol., 9, 388-407, 2008.

Wang, W., Xie, P., Yoo, S.-H., Xue, Y., Kumar, A., and Wu, X.: An assessment of the surface climate in the NCEP climate forecast system reanalysis, Clim. Dynam., 37, 1601-1620, 2013.

Weedon, G. P., Balsamo, G., Bellouin, N., Gomes, S., Best, M. J., and Viterbo, P.: The WFDEI meteorological forcing data set: WATCH Forcing Data methodology applied to ERA-Interim reanalysis data, Water Resour. Res., 50, 7505-7514, 2014.

Willmott, C. J., Robeson, S. M., and Matsuura, K.: Climate and other models may be more accurate than reported, Eos, 98, https://doi.org/10.1029/2017EO074939, 2017.

Xie, P. and Arkin, P. A.: Global precipitation: a 17-year monthly analysis based on gauge observations, satellite estimates, and numerical model outputs, B. Am. Meteorol. Soc., 78, 2539-2558, 1997.
Xu, R., Tian, F., Yang, L., Hu, H., Lu, H., and Hou, A.: Ground validation of GPM IMERG and TRMM 3B42V7 rainfall products over southern Tibetan Plateau based on a high-density rain gauge network, J. Geophys. Res.-Atmos., 122, 910-924, 2017.

Yong, B., Liu, D., Gourley, J. J., Tian, Y., Huffman, G. J., Ren, L., and Hong, Y.: Global view of real-time TRMM Multisatellite Precipitation Analysis: Implications for its successor Global Precipitation Measurement mission, B. Am. Meteorol. Soc., 96, 283-296, 2015.

Zambrano-Bigiarini, M., Nauditt, A., Birkel, C., Verbist, K., and Ribbe, L.: Temporal and spatial evaluation of satellite-based rainfall estimates across the complex topographical and climatic gradients of Chile, Hydrol. Earth Syst. Sci., 21, 1295-1320, https://doi.org/10.5194/hess-21-1295-2017, 2017.

Zhu, H., Wheeler, M. C., Sobel, A. H., and Hudson, D.: Seamless precipitation prediction skill in the tropics and extratropics from a global model, Mon. Weather Rev., 142, 1556-1569, 2014.

Zolina, O., Kapala, A., Simmer, C., and Gulev, S. K.: Analysis of extreme precipitation over Europe from different reanalyses: a comparative assessment, Global Planet. Change, 44, 129-161, 2004. 